
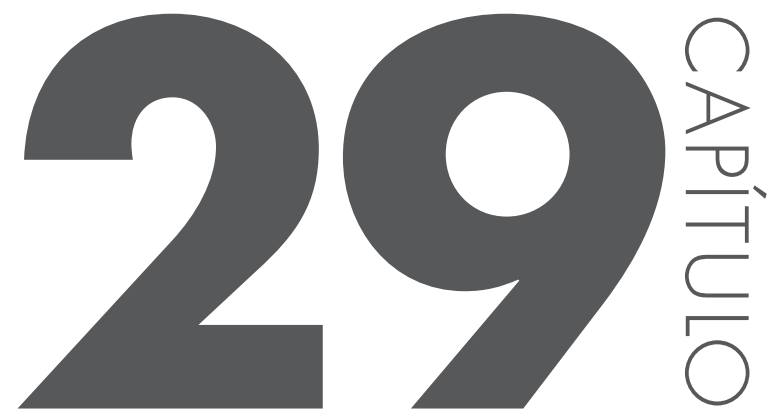

\title{
BASES DA RESPOSTA INFLAMATÓRIA DO TRATO GASTRINTESTINAL
}

Ronaldo de Albuquerque Ribeiro Roberto César Pereira Lima Júnior Marcellus Henrique Loiola Ponte de Souza Caio Abner Vitorino Gonçalves Leite Carlos Wagner de Souza Wanderley

\subsection{INTRODUC̣ÃO}

A inflamação é uma resposta vascular, celular e humoral, responsável pelo processo de defesa dos organismos vivos ante agentes agressores. Essa resposta fisiológica é resultante da ação coordenada entre o sistema imunológico e o tecido no qual ocorreu a lesão. Por incorporar vários mecanismos biológicos, como a formação de edema, fagocitose, angiogênese, fibroplasia, liberação de mediadores químicos, além de outros fatores, a inflamação passou a ser entendida como um processo, proveniente de uma soma de eventos, que, de acordo com o tempo de evolução e as características patológicas envolvidas, pode ser classificada em inflamação aguda ou crônica (KUMAR, 2010). 
No trato gastrintestinal (TGI) a resposta inflamatória é constante em razão da contínua exposição a agentes externos incluindo micro-organismos, antígenos e grande quantidade de enzimas digestivas que possuem potencial para comprometer a integridade dos tecidos do TGI. Componentes do sistema imune, como nódulos linfáticos, imunoglobulinas, macrófagos e células linfoides são bastante abundantes por todo o TGI. A associação destes elementos com a elevada capacidade proliferativa dos enterócitos compõe a barreira física e imunológica capaz de regular a homeostase entre a mucosa intestinal e os micro-organismos por via de uma constante e controlada resposta inflamatória.

Essa resposta pode ocorrer de forma desequilibrada e apresentar um caráter nocivo ao organismo. Nesse ponto, a própria resposta imune pode contribuir diretamente para o desenvolvimento de eventos patológicos comumente observados nas doenças inflamatórias intestinais (DIIs), como será melhor descrito a seguir.

\subsection{AGENTES INICIADORES DA RESPOSTA INFLAMATÓRIA}

\subsubsection{PAPEL DOS RECEPTORES DE RECONHECIMENTO DE PADRÕES (PPRS) NA DEFESA DA MUCOSA DO TGI}

Além das barreiras físicas que limitam a entrada de agentes patogênicos no organismo do TGI, existe uma série de receptores, amplamente distribuídos ao longo de toda a mucosa gastrintestinal, especializados em identificar imunógenos. $\mathrm{O}$ processo de reconhecimento de agentes patogênicos é altamente específico e ocorre pela ligação entre os padrões moleculares associados aos patógenos (PAMPs) e os receptores de reconhecimento de padrões (PRRs). Os PRRs conhecidos são classificados como: Receptores Toll-Like (TLRs), Receptores Nod-Like (NLRs), e Receptores Rig-1-Like (RLRs).

\subsubsection{RECEPTORES TOLL-LIKE (TLRS)}

Em mamíferos, os TLRs compreendem uma família com 12 tipos de receptores, sendo os TLRs 1-9 mais facilmente encontrados nas células do intestino delgado e grosso. Em humanos, apenas os TLRs 2, 3, 4, 5, e 9 foram consistentemente identificados, com destaque para os TLR-3 e TLR-5 que estão em maior número nos colonócitos e enterócitos humanos. Os TLRs são encontrados na membrana plasmática ou em compartimentos endossomais intracelulares. Estruturalmente, os TLRs são classificados como receptores transmembrana e possuem três carac- 
terísticas comuns: um domínio extracelular contendo repetições ricas em leucina (LRR), uma região transmembrana curta, e um domínio intracelular homologo ao do receptor para IL-1 conhecido como TIR (Receptor Toll/IL-1) essencial para a transdução dos sinais (MARQUES, 2011; SIGGERS, 2011).

A ativação desses receptores é realizada por PAMPs que possuem relativa especificidade aos distintos TLRs. O TLR-2, por exemplo, identifica peptídeoglicanos e lipoproteínas, o TLR-3 identifica o RNA viral, o TLR-4 reconhece o lipopolissacarídeo (LPS), o TLR-5 reconhece a flagelina e o TLR-9 liga-se ao DNA bacteriano. Apesar do pequeno número de receptores, esta distribuição reflete elevada capacidade de identificar os padrões moleculares em diversos agentes patogênicos. Este processo de reconhecimento dará início à resposta imune inata caracterizada pela secreção de citocinas e quimiocinas e aumento da expressão de moléculas de adesão. A ação conjunta desses fatores irá estimular e facilitar a migração de células especializadas responsáveis por desencadear a resposta imune inata e, posteriormente, a adaptativa.

Os TLRs 2 e 4 estão classicamente envolvidos neste processo de reconhecimento de PAMPs. Contudo, estudos tem demonstrado que estes TLRs também são capazes de reconhecer ligantes não microbianos, incluído padrões moleculares associados a danos (DAMPs) e outros produtos do tecido inflamado, não necessariamente associados a um processo infeccioso, o que pode ser definido como inflamação estéril.

O contato dos TLRs 2 e 4 com PAMPs e DAMPs resulta na ativação celular que dará inicio à resposta imune inata. A via mais comum de ativação envolve o domínio Toll/Interleucina-1 (TIR) dos TLRs. Este domínio inicia o recrutamento da proteína adaptadora da resposta mieloide primária 88 (MyD88) e a consequente ativação da quinase associada ao receptor da IL-1 (IRAK). A ativação da IRAK induz a ativação de serina e treonina quinases responsáveis pela degradação do I $\mathrm{B} \alpha$ (inibidor do fator nuclear de transcrição $\kappa \mathrm{B}[\mathrm{NF}-\kappa \mathrm{B}]$ ). A diminuição das concentrações citoplasmáticas de $\mathrm{I} \kappa \mathrm{B} \alpha$ permite que o $\mathrm{NF}-\kappa \mathrm{B}$, se desloque do citoplasma para o núcleo. Uma vez no núcleo da célula, o NF-кB interage com genes $\kappa \mathrm{B}$ dependentes, induzindo a produção de citocinas pró-inflamatórias e outros mediadores inflamatórios importantes para a resposta imune (Figura 29.1).

Além dessa, existe uma via de sinalização alternativa à MyD88 que envolve o TLR-3 e o TLR-4 (o TLR-4 é o único TLR capaz de ativar a via clássica e a alternativa). A via alternativa é mediada pela ativação do TRIF (receptor contendo o domínio adaptador de indução do interferon- $\beta$, IFN- $\beta$ ) e TRAM (molécula adaptadora relacionada ao TRIF). Estes adaptadores atuam sobre o IRF-3 (fator de transcrição regulador do interferon 3 ) estimulando a síntese de interferon- $\beta$ (IFN- $\beta$ ) que auxiliará no combate a vírus através da inibição da replicação do RNA 
viral e aumento do recrutamento de células natural kilier (NK) e macrófagos para o local da infecção (Figura 29.1).

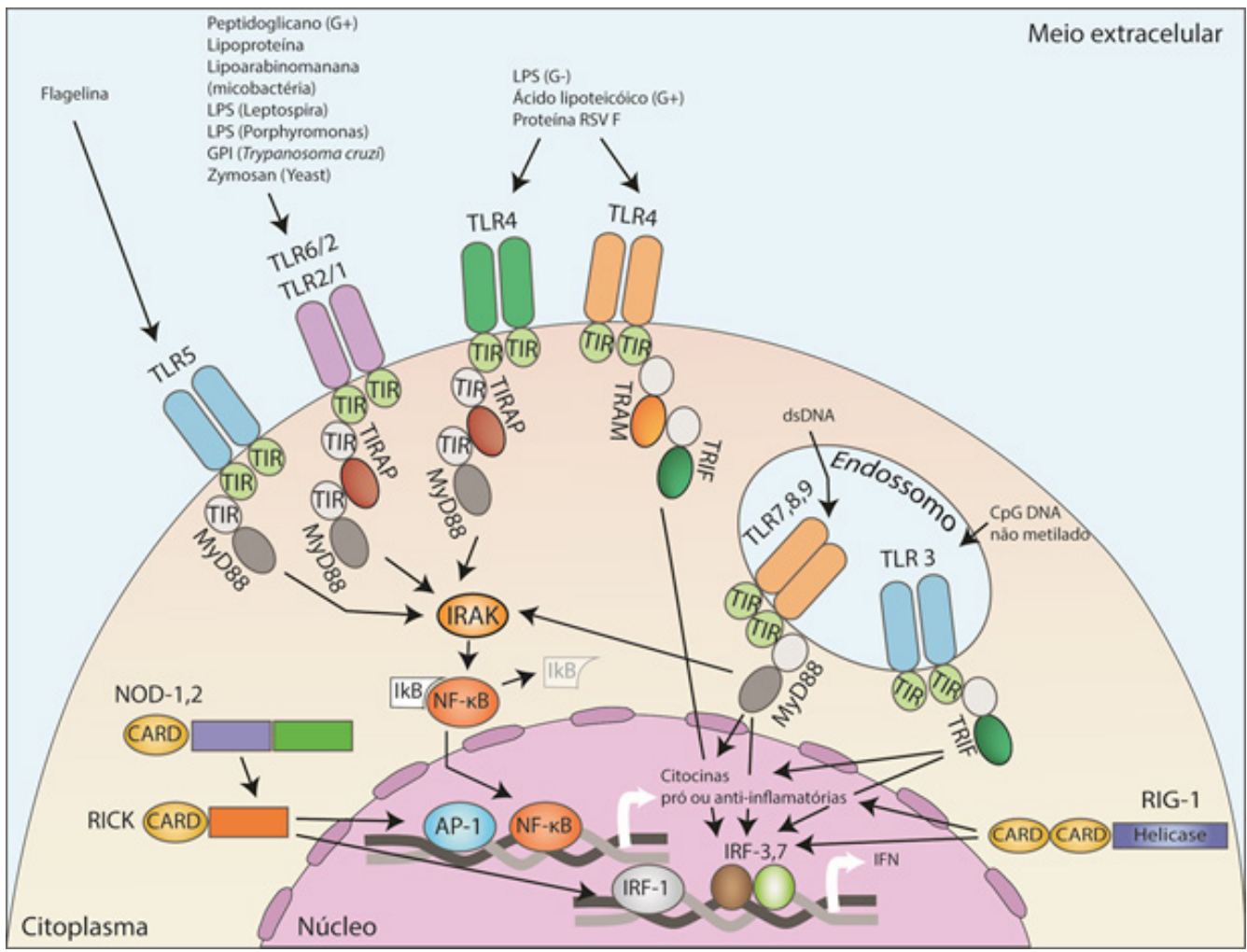

Figura 29.1 - Via de sinalização dos PRRs (TLRs, NODs e RIGs). Estruturalmente, os TLRs são receptores transmembrana e possuem um domínio extracelular contendo repetiçōes ricas em leucina (LRR), uma região transmembranar curta e um domínio intracelular homologo ao do receptor para IL-I, conhecido como TIR (Domínio receptor Toll/IL-I). A ativação desses receptores é realizada por PAMPs (como DNA dupla fita, lipopolissacarídeo - LPS - bacteriano) ou DAMPs. A via mais comum de ativação envolve o domínio TIR dos TLRs e a via alternativa envolve a ativação do TRIF. Estes domínios iniciam 0 recrutamento da MyD88 e consequente ativação da quinase associada ao receptor da IL-I (IRAK). A ativação da IRAK induz a ativação de serina e treonina quinases responsáveis pela degradação do $1 \kappa B \alpha$. A diminuição das concentrações citoplasmáticas de $\mathrm{\kappa} \kappa \mathrm{B} \alpha$ permite que $0 \mathrm{NF}-\kappa \mathrm{K}$, se desloque do citoplasma para o núcleo. Uma vez no núcleo da célula, $0 \mathrm{NF}-\kappa \mathrm{B}$ interage com genes $\kappa B$ dependentes, induzindo a produção de citocinas e outros mediadores inflamatórios importantes para a resposta imune. Os receptores NOD-1 e NOD-2 juntos reconhecem o dipeptídeo iE-DAP e o muramil dipeptídeo (MDP) presente em praticamente todos os tipos de bactérias Gram-positivas e negativas, o contato com estes ligantes provoca a ativação de fatores de transcrição pró-inflamatórios como o NF-KB, Proteína Ativadora 1 (AP-1) ou Fator de Transcrição Regulador de Interferon (IRF-1) e consequente expressão de mediadores que estimulam a resposta imune. A ativação das vias de sinalização do RIG-1 estimula a produção de Interferon (IFN- $\beta$ ), através da ativação dos fatores de transcrição IRF-3,7 e NF- $\kappa B$ com consequente produção de citocinas pró-inflamatórias (Figura adaptada de MÜLLER, 2009). 
No epitélio gastrintestinal o TLR-5, receptor especializado em reconhecer a flagelina em bactérias como a Salmonella e a Escherichia coli, é restrito à membrana basolateral do enterócito. Esta condição sugere que a flagelina, no lúmen intestinal, é tolerada, fato que contribui para a manutenção do equilíbrio com a microbiota comensal em uma condição de homeostase. Quando ocorre, porém, uma ruptura da barreira epitelial, os receptores TLR-5 dos enterócitos entram em contato com a flagelina, iniciando a resposta inflamatória e imune de defesa do organismo.

O TLR-5, uma vez em contato com a flagelina, realiza a transdução do sinal via proteína MyD88 que inicia uma complexa série de eventos envolvendo o TRAF-6 (Fator 6 Associado ao Receptor de Fator de Necrose Tumoral) e a IRAK culminando com a ativação de fatores de transcrição como a proteína ativadora

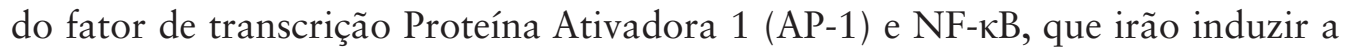
produção de citocinas pró-inflamatórias (IL-1, IL-6 e TNF- $\alpha$ ) (Figura 29.1).

O NF- $\kappa B$, uma vez ativado, ainda é capaz de induzir a produção de quimiocinas como a IL-8, CCL20, MIP1 $\alpha$ (proteína inflamatória de macrófagos-1 $\alpha$ ), entre outros, e assim atrair neutrófilos, macrófagos, células dendríticas, células T CD 4+, e células B para o local da infecção. Desta forma, através da ligação dos PAMPs aos TLRs, as células epiteliais da mucosa gástrica, pelas vias de transdução de sinais semelhantes, são capazes de ativar as respostas inatas e adaptativas atraindo células como neutrófilos, células dendríticas e ativando células T auxiliares.

Sendo assim, as células epiteliais do TGI que expressam TLRs auxiliam na regulação da produção de citocinas e quimiocinas e da ativação da resposta imune inata e adaptativa. Consequentemente, o papel dos TLRs na fisiopatologia de algumas doenças inflamatórias do TGI é bastante investigado. Trabalhos recentes demonstraram que a expressão dos TLRs 2, 3, 5, e 9 no epitélio de pacientes com doença inflamatória intestinal (DII) mostrou-se reduzida, ao contrário da expressão de TLR-4, que estava aumentada, e nos enterócitos de camundongos e humanos com enterocolite necrosante (NEC); contudo, em modelos murinos de colite utilizando animais knockout foi constatado que a ausência de TLRs 2, 3, 5 e 9 resultava em uma doença inflamatória muito mais grave.

Estes resultados sugerem que alguns receptores, como o TLR-4, têm expressão aumentada em quadros patológicos e contribui diretamente na fisiopatologia dessas doenças; entretanto, é importante considerar que a deficiência de TLRs também pode provocar danos ao organismo, provavelmente devido à participação dos TLRs como agentes iniciadores da resposta imune inata. Desta forma, considerando que tanto o excesso quanto a ausência destes receptores podem ser prejudiciais à saúde, pesquisas têm sido realizadas com o intuito de investigar as relações cruzadas existentes entre os TLRs e a possibilidade de modular a parti- 
cipação destes durante os processos patológicos. Neste sentido, a relação entre o TLR-9 e o TLR-4 vem sendo bastante discutida na literatura.

O TLR-9, um receptor sensível ao DNA microbiano, tem demonstrado uma participação significativa dentro da resposta inflamatória intestinal. Este receptor está localizado no citoplasma celular onde pode ser ativado por um dinucleotídeo, o CpG (Citosina-Guanosina). A ativação do TLR-9 leva a formação de produtos de reconhecida ação pró-inflamatória como o TNF- $\alpha$, IL-6 e IL-12 e a ativação da resposta inflamatória do tipo Th1.

Apesar de possuir estas fortes propriedades imunoestimulatórias, estudos recentes têm demonstrado que a ativação dos receptores TLR-9 parece ser eficaz em reduzir a apoptose de células epiteliais em vários modelos de doença inflamatória gastrintestinal. Na colite experimental em murinos, a administração de $\mathrm{CpG}$ reduziu significativamente a expressão de citocinas pró-inflamatórias como o IFN-g e IL-6, e aumentou a expressão de IL-10, uma potente interleucina anti-inflamatória, reduzindo a gravidade da doença em vários aspectos.

Em outro estudo, a administração de oligômeros de CpG, no modelo de enterocolite necrosante em neonatos, também demonstrou efeito anti-inflamatório interessante. Acredita-se que a estimulação do TLR-9 iniba a expressão gênica de TLR-4 e a consequente produção de citocinas inflamatórias e a apoptose celular dependentes da ativação deste receptor. Contudo, em outro modelo experimental de colite, a administração de $\mathrm{CpG}$ apresentou efeito contrário ao descrito anteriormente, agravando a doença. Estes resultados não deixam claros os mecanismos desencadeados após a ativação dos TLR-9 e qual a sua relação com os TLR-4. Desta forma, tal conhecimento poderia abrir perspectivas para o estudo de possíveis alternativas terapêuticas envolvendo a modulação das vias de sinalização dos receptores TLRs.

\subsubsection{RECEPTORES NOD-LIKE (NLRS)}

Os receptores Nod-Like (NLRs) e os receptores RIG-1-like (RLRs), descobertos mais recentemente, são reconhecidos como sensores intracelulares importantes para o desenvolvimento da imunidade inata. Estes receptores PRRs no interior das células sugerem a existência de uma segunda linha de defesa capaz de ativar a resposta imune inata, caso haja a passagem de um agente patogênico através das barreiras primárias localizadas no meio extracelular e dos receptores TLRs localizados na membrana citoplasmática dos enterócitos.

Os receptores NLRs compreendem uma grande família de PRRs intracelulares caracterizada por um domínio conservado. Estudos recentes demonstraram 
a existência de 23 genes de NLRs diferentes no genoma humano. Em ratos, até o momento, foram descobertos 34 NLRs diferentes.

Destes, os mais estudados são o NOD-1 e o NOD-2. Estes receptores são sensíveis a moléculas bacterianas produzidas durante a síntese e/ou degradação do peptideoglicano da membrana das bactérias Gram-positivas e Gram-negativas. O NOD-1 é especializado no reconhecimento do dipeptídeo iE-DAP (Ácido $\gamma$-D-glutamil-meso-diaminopimelico) que está presente em bactérias Gram-negativas e apenas em algumas Gram-positivas. Em contraste, o NOD-2 é ativado pelo muramil dipeptídeo (MDP) um componente presente em praticamente todos os tipos de bactérias Gram-positivas e Gram-negativas.

A ativação resultante do contato entre receptores NOD-1 ou NOD-2 e iEDAP ou MDP provoca uma rápida resposta envolvendo a ativação de fatores de transcrição pró-inflamatórios como o NF-кB, AP1 ou IRF-1 (Fator de Transcrição Regulador de Interferon - 1) e consequente expressão de mediadores inflamatórios que estimularam a resposta imune inata e adaptativa (Figura 29.1).

Além disso, as moléculas adaptadoras associadas à apoptose contendo um domínio CARD (ASC), IPAF, criopirina/NALP3 apresentam um papel importante na ativação da caspase-1 em um complexo multi-proteico chamado inflamassoma, que é fundamental para induzir a produção de citocinas através da clivagem das pró-IL-1 $\beta$ e pró-IL-18 em suas formas ativas. A IL-1 $\beta$ promove, dentre outros efeitos, ativação endotelial com consequente recrutamento celular, enquanto que a IL-18 promove amplificação da resposta mediada por linfócitos $\mathrm{T}$ auxiliares tipo 1 (Th1), estimulando a ativação de uma resposta inflamatória mais intensa.

Trabalhos recentes indicam que a atividade dos receptores NLRs poderia auxiliar de forma complementar e/ou sinérgica à atividade dos receptores TLRs na manutenção da homeostase intestinal. Qualquer defeito na função de TLRs e NLRs pode levar ao desenvolvimento de doença inflamatória crônica e aumentar a susceptibilidade a doenças infecciosas.

A existência de uma dinâmica relação cruzada bem estabelecida entre os receptores NOD-2, TLR-9 e TLR-4 capaz de regular a homeostase do TGI tem sido investigada. Acredita-se que o receptor TLR-4 em contato com PAMPs específicos (como o LPS) conduz uma série de modificações na superfície da membrana dos enterócitos que possibilitam a internalização de patógenos. Esse processo é necessário para a apresentação de antigéno e consequente ativação dos receptores TLR-9 e NOD-2, que se encontram no meio intracelular. A ativação desses receptores intracelulares inicia uma resposta capaz de limitar a sinalização e a expressão de TLR-4, impedindo a entrada de material bacteriano adicional para o citoplasma, além de limitar os efeitos pró-inflamatórios exagerados do TLR-4, que são capazes de induzir uma lesão com ruptura da barreira epitelial. 


\subsubsection{RECEPTORES RIG-LIKE (RLRS)}

Os receptores RIG-like (RLRs) são conhecidos como sensores intracelulares responsáveis pela ativação da resposta imune inata contra vírus; contudo, há evidências que demonstram haver RLRs na superfície apical do epitélio intestinal obtido de biopsias de cólon humano. Estas evidências sugerem que os RLRs possuem alguma função na regulação da homeostase no TGI.

Estudos recentes têm demonstrando que a ativação da proteína sinalizadora mitocondrial antiviral (MAVS), também conhecida como IPS-1, VISA, ou CARDIF, pela via de transdução de sinais oriundos da ativação dos RLRs poderiam ser importantes para a manutenção da homeostase intestinal e ativação da resposta imune inata no TGI.

Acredita-se que a ativação das vias de sinalização do RIG-1 estimula a produção de interferon tipo 1 (IFN- $\beta$ ), via CARD recruta o MAVS que atua como um adaptador essencial para ativar fatores de transcrição IRF-3 e NF- $\kappa$ B e consequente indução de citocinas pró-inflamatórias; no entanto, o mecanismo pelo qual RIG-1 regula a inflamação intestinal permanece mal compreendido (Figura 29.1).

Desta forma, no complexo sistema de defesa do organismo o epitélio gastrintestinal é muito mais do que uma simples barreira física. A habilidade de reconhecer potenciais agentes patogênicos, atribuída à camada epitelial, passou a ser vista como um fator primário regulador da resposta imune das mucosas. Esse processo de reconhecimento e modulação da resposta imune só é possível devido à existência de PRRs nas células epiteliais e a sua função é indispensável para a regulação da homeostase e ativação da imunidade inata no TGI quando necessário.

\subsubsection{CÉLULAS APRESENTADORAS DE ANTÍGENOS (CAA)}

A resposta imunológica pode ser classificada em resposta imune inata e adquirida; entretanto, esses eventos não são completamente distintos. Existem componentes do sistema imune capazes de interagir com elementos das duas fases da resposta inflamatória. No TGI existem células especializadas capazes de ligar a imunidade inata à adquirida. Esse conjunto de células, também conhecido como células apresentadoras de antígenos (CAA), é composto por células M (Microfold), células dendríticas e macrófagos. 


\subsubsection{CÉLULA M}

No intestino, o principal local de processamento de antígenos ocorre nas placas de Payer, um aglomerado de nódulos linfáticos periféricos, rico em células imunes especialmente linfócitos $\mathrm{B}$ e $\mathrm{T}$. Os antígenos luminais ganham acesso às placas de Payer via transferência mediada por células epiteliais diferenciadas conhecidas como células $\mathrm{M}$, que estão dispersas entre o tecido epitelial colunar e o folículo associado ao epitélio localizado sobre as Placas de Payer.

As células $\mathrm{M}$ expressam o complexo de histocompatibilidade do tipo II (MHC-II) e são capazes de produzir IL-1. Além disso, tem sido sugerido que estas células seriam aptas a apresentar antígenos diretamente às células $\mathrm{T}$ localizadas nas placas de Payer; contudo, em virtude da sua localização, acredita-se que este mecanismo de apresentação direta seja limitado e que as células dendríticas estariam envolvidas no reconhecimento, processamento e apresentação dos antígenos internalizados pelas células M (Figura 29.2). 


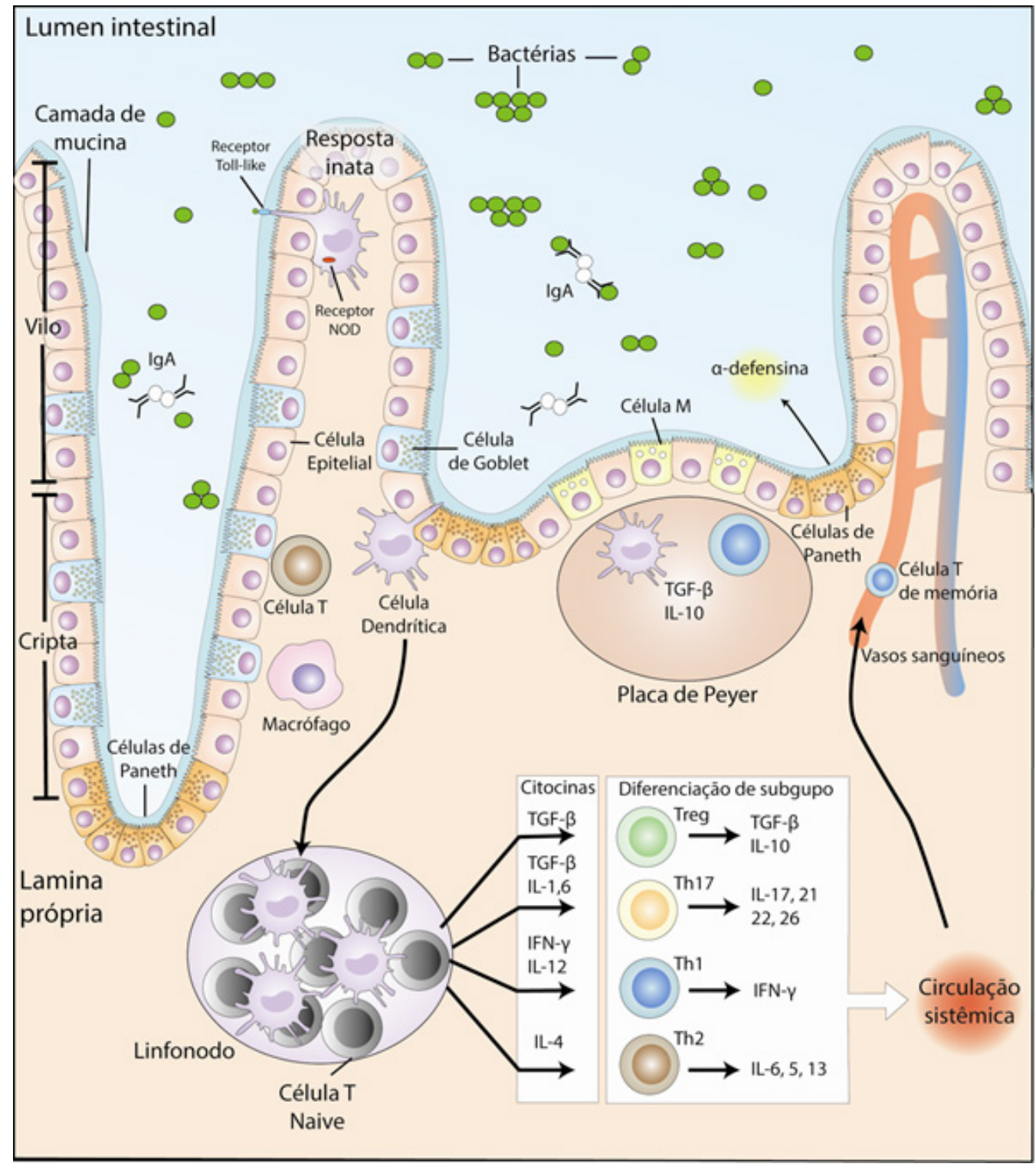

Figura 29.2 - 0 sistema imune intestinal. № intestino, o tecido linfóide associado à mucosa é representado pelas placas de Peyer, que são recobertas por células epiteliais especializadas, as células M. Estas células são capazes de endocitar antígenos presentes no lúmen intestinal e transportá-los através de vesículas de transcitose até os folículos subjacentes. Estes folículos são ricos em células Dendríticas capazes de processar o antígeno e apresentá-lo as células $T$ dando inicio a uma resposta $T$ CD4 + com ativarģão de células B e consequente produção seletiva de imunoglobulinas IgA. No lúmen intestinal, a lgA tem a capacidade de ligar-se inespecificamente a antígenos presentes na superfície mucosa. Este efeito neutraliza a ação do antígeno impedindo a penetração e a aderência deste à camada epitelial da mucosa. A IgA possui afinidade não-espećifica com mucinas secretadas pela mucosa intestinal e a formação do complexo antígeno-IgA aumenta a retenção de microorga- 
nismos patogênicos ao muco e estimula sua secreção, facilitando a degradação enzimática e a eliminação do antígeno sem haver a necessidade de ativar a resposta inflamatória. As células Dendríticas da lâmina própria da mucosa podem emitir pequenos braços, chamados de den-dritos, para o lúmen intestinal. Esta característica permite que estas células dendríticas fagocitem microrganismos comensais ou patogênicos presentes no lúmen. Após a internalização dos antígenos por fagocitose, as células dendríticas imaturas migram para os linfonodos mais próximos, onde amadurecem, tornando-se capazes de apresentar antígenos aos linfócitos T naïve. Após a apresentação dos antígenos a polarização das células T naïve para as diferentes vias da resposta imune (Treg, Th17, Th1 e Th2) é dependente do perfil de citocinas que pode estar envolvido. Uma vez polarizadas essas células ganham a circulação para realizar suas funções efetoras (Figura adaptada de Abraham et al. 2009).

\subsubsection{CÉLULA DENDRÍTICA}

As células dendríticas compõem o grupo de células vigilantes do intestino, muito importantes para o desenvolvimento da imunidade adaptativa. Essas células podem ser divididas em subgrupos, dependendo da expressão de receptores CX3CR1 (o receptor da fractalcina) e CD103 (integrina- $\alpha$ E). As células dendríticas CX3CR1+ são derivadas de precursores monocíticos da medula óssea e expandidas na presença de ligante para o receptor tirosina quinase fetal e de fígado (Flt3L). Já as células dendríticas CD103+ são derivadas de precursores de células dentríticas circulantes e expandidas na presença de Fator Estimulador de Colônias de Monócitos (M-CSF). Estas células no TGI controlam as complexas interações da microbiota do intestino com a resposta imune inata e adaptativa, modulando a tolerância aos micro-organismos comensais, e a resposta imune aos patogênicos.

As células dendríticas CX3CR1/CD103- ficam alojadas na lâmina própria da mucosa onde são capazes de emitir pequenos braços, chamados de dendritos, que passam entre as células epiteliais e chegam ao lúmen intestinal. Esta característica permite que estas células dendríticas fagocitem micro-organismos comensais ou patogênicos do lúmen intestinal (Figura 29.2).

Após a internalização dos antígenos por fagocitose, as células dendríticas imaturas migram para os linfonodos mais próximos, onde amadurecem, tornando-se capazes de apresentar antígenos aos linfócitos T (Figura 29.2). Sugere-se que somente as células CD103+ sejam capazes de migrar para os linfonodos. Durante a migração e a maturação, as células dendríticas passam por significantes mudanças morfológicas, que diminuem a habilidade de processar novos antígenos e aumentam a capacidade de apresentar antígenos às células $\mathrm{T}$. $\mathrm{O}$ aumento na habilidade de apresentar antígenos está relacionado com o aumento na expressão do MHC-II na superfície celular, e do aumento na produção de moléculas co-estimulatórias, de adesão e citocinas. 
Além disso, as células dendríticas $\mathrm{CD} 103^{+}$são capazes de modular a resposta inflamatória pela ativação de um subgrupo de células $\mathrm{T}$, as células $\mathrm{T}$ reguladoras (Treg). Essas células, reconhecidas por sua importante atividade imunossupressora endógena, quando ativadas por células APCs, como as células dendríticas, sinalizam via fator de transcrição nuclear Foxp $3^{+}$e iniciam vários mecanismos supressores. Esses mecanismos consistem na liberação de citocinas inibitórias (IL-10, IL-35 e TGF- $\beta$ ) contribuindo para a manutenção da homeostase (MELO 2009) (Figura 29.2).

As células dendríticas $\mathrm{CD} 103^{+}$também podem entrar em contato com antígenos intestinais por outro mecanismo. Este mecanismo alternativo envolve as células $\mathrm{M}$ e as células epiteliais da mucosa gástrica, que são capazes de reconhecer antígenos no lúmen intestinal, internalizá-los e apresentá-los às células dendríticas localizadas na lâmina própria da mucosa. Estas fagocitam esses antígenos e os apresentam às células $\mathrm{T}$, cursando com a ativação de linfócitos $\mathrm{B}$ e aumento da produção de anticorpos como a IgA e diversas citocinas importantes para a modulação da resposta imune.

Adicionalmente, as células dendríticas possuem receptores Toll-like (TLRs) como o TLR-2, TLR-4 e TLR-9. Quando uma célula epitelial ou uma célula M apresenta um antígeno à célula dendrítica, esta identifica a molécula via TLRs. Esse evento ativa diversas vias intracelulares como o MyD88, NF-кB e MAPK, estimulando a produção de IL-12 por estas células. A IL-12 por sua vez influencia a diferenciação de uma resposta pró-inflamatória do tipo Th1. Este mecanismo tem sido implicado na fisiopatologia da doença de Crohn, que também possui uma conhecida resposta imunológica fortemente polarizada Th1, com abundante participação de IL-12.

\subsubsection{MACRÓFAGOS INTESTINAIS RESIDENTES}

Os macrófagos compõem outro importante grupo de células responsáveis por fazer a ponte entre a imunidade inata e adquirida. No trato gastrintestinal, os macrófagos residentes estão quase que exclusivamente na lâmina própria do intestino e do cólon. Esta localização estratégica garante uma linha de defesa da mucosa contra potenciais micro-organismos patogênicos e a regulação do equilíbrio com a microbiota comensal.

No intestino, os macrófagos residentes apresentam características morfológicas e funcionais diferenciadas e particulares. Basicamente, essas células são fagócitos hiporresponsivos a vários estímulos inflamatórios e espontaneamente secretam IL-10 e regulam a atividade de células Treg via ativação do FoxP3+ na presença de TGF- $\beta$ (DENNING et al. 2007). Nestas células, os receptores de 
resposta imune como: CD14 (reconhece LPS), Fc $\gamma$ e Fc $\alpha$ (reconhece anticorpos específicos), TLR-2 e TLR-4 (reconhece peptídeoglicanos e LPS, respectivamente) estão pouco expressos. A baixa expressão desses receptores pode influenciar no tipo de resposta imune. Um estudo utilizando macrófagos isolados do intestino humano, essas células foram incapazes de produzir citocinas (IL-1, IL-6, IL-8, e TNF- $\alpha$ ) em resposta a estímulos inflamatórios, incluindo componentes bacterianos como LPS. Contudo, a capacidade fagocítica e bactericida dessas células ainda são mantidas e preservadas, apesar de que, devido à ausência do CD14, os macrófagos intestinais parecem ser incapazes de realizar a explosão oxidativa (MESTECKY J. et al. 2005).

Os macrófagos intestinais expressam moléculas com atividade antiinflamatória, incluindo IL-10, além de modular a atividade das células Treg por um mecanismo dependente de IL-10 e ácido retinoico. Assim, os macrófagos intestinais passaram a ser considerados importantes para a manutenção da homeostase, por protegerem o organismo da entrada de agentes patogênicos e ao mesmo tempo regularem negativamente a resposta inflamatória exagerada. Um exemplo da importância local dessas células foi demonstrado por meio da depleção dos macrófagos intestinais utilizando clodronato, levando a uma exacerbada colite experimental induzida com dextrana sulfato de sódio (DSS).

Por outro lado, as respostas imunes anormais aos micro-organismos comensais muitas vezes são as responsáveis pelo desenvolvimento e evolução de várias doenças intestinais, sendo que algumas subfamílias de macrófagos podem contribuir na patogênese da inflamação intestinal em humanos e camundongos. Por exemplo, macrófagos originados de monócitos sanguíneos e que apresentam o receptor ativador expresso em células mielóides-1 (TREM-1 ${ }^{+}$), que amplificam a resposta pró-inflamatória por induzir a secreção de citocinas, parecem participar na patogênese da doença de Crohn e da doença inflamatória intestinal (DII) via produção excessiva de IL-23 e TNF- $\alpha$ em resposta a bactérias comensais.

Estes achados permitem propor que os macrófagos residentes do intestino teriam um papel importante para a manutenção da tolerância e regulação da resposta inflamatória intestinal, enquanto, os macrófagos oriundos da diferenciação dos monócitos sanguíneos nos tecidos estariam relacionados diretamente à patogênese das doenças inflamatórias intestinais como a doença de Crohn e outras DIIs. 


\subsubsection{PAPEL DOS LINFÓCITOS TH1, TH2 E TH17 NA IMUNIDADE E INFLAMAÇÃO DA MUCOSA INTESTINAL}

A resposta imunológica adaptativa a um agente patogênico não é simplesmente de uma resposta específica contra um patógeno, mas sim de uma resposta inflamatória significativamente mais eficiente. A descoberta das subfamílias de células T CD4+ Th1/Th2 redefiniu o entendimento da imunidade e o papel de destaque de algumas citocinas na indução e regulação da resposta imune adquirida. Mais recentemente, foi identificada mais uma subfamília de células $T$, as células Th17, cuja atividade tem sido fortemente associada à interleucina 23 (IL-23). Contudo, o real papel da IL-23/Th17 na resposta imune ainda é controverso, uma vez que a resposta IL-23/Th17 pode estar envolvida tanto em processos inflamatórios intestinais crônicos quanto na regulação da homeostase da mucosa do TGI.

\subsubsection{COMPONENTES DA RESPOSTA IMUNE ADQUIRIDA NO TGI}

O desenvolvimento da resposta adquirida requer a participação de linfócitos $\mathrm{T}$, como as células T naïve, que expressam a proteína CD4 ou CD8 na membrana plasmática. Após o contato com as APCs, a célula Th $\mathrm{CD}^{+}$é alvo de expansão clonal regulada pela ação autócrina da IL-2 e, a seguir, de acordo com o padrão do estímulo imposto por citocinas IL-12, IL-4 ou IL-23, a resposta pode ser desenvolvida no sentido das subfamílias Th1, Th2 ou Th17.

Além disso, existem os linfócitos B, que, ao interagir com linfócitos Th2, se diferenciam em plasmócitos produtores de anticorpos ou linfócitos B de memória. Outro grupo de células que, embora numericamente pequeno, desempenha importantes funções no desenvolvimento da imunidade contra células infectadas ou neoplásicas são as células Natural Killer (NK), um mecanismo de citotoxicidade regulado pela IL-13.

Vale ressaltar ainda que a participação desses linfócitos na resposta imune, na inflamação e na tolerância a agentes patogênicos nas mucosas, pode ser modulada por outro grupo especial de células T, conhecidas como células $\mathrm{T}$ reguladoras (Treg) (MESTECKY J. et al. 2005).

Na mucosa do TGI, todos esses linfócitos estão distribuídos ao longo de três regiões: na camada epitelial, na lâmina própria e em coleções celulares repletas de linfócitos T e B chamadas de Placas de Payer. Dentre os tecidos linfóides organizados do intestino as placas de payer são as mais importantes (Figura 29.2). Estrategicamente localizadas na camada mucosa e submucosa do intestino, as placas de Payer consistem em um aglomerado de nódulos linfáticos, com a região 
central rica em linfócitos B que representam 50 a $70 \%$ dos linfócitos, enquanto que os linfócitos T representam 10 a $30 \%$ do total de células.

A maioria dos linfócitos localizados próximo às células epiteliais expressa a molécula CD8em suas membranas; contudo, nestas células, o número de receptores para antígenos é considerado limitado quando comparado aos demais tipos de células $\mathrm{T}$. $\mathrm{Na}$ lâmina própria intestinal é possível identificar linfócitos T, que são em sua maioria do tipo CD4+ e que estão constantemente ativados. É provável que essas células reconheçam antígenos ainda na lâmina própria e respondam a esses nos linfonodos mesentéricos que drenam o intestino, retornando para a lâmina própria como células $\mathrm{T}$ ativadas.

\subsubsection{ATIVAÇÃO DOS LINFÓCITOS E O INICIO DA IMUNIDADE ADQUIRIDA}

Quando ocorre o rompimento da barreia intestinal e a exposição da mucosa aos micro-organismos luminais, as APCs, incluindo macrófagos, células dendríticas e até mesmo as células epiteliais intestinais, fagocitam, processam e apresentam partes do agente invasor para as células $\mathrm{T} \mathrm{CD}^{+}$naïve, localizados nas placas de Payer, via complexo de histocampatibilidade do tipo II (MHC II).

Após a apresentação, ocorre o desenvolvimento da imunidade adquirida que é dividida em duas fases distintas: a primeira fase é conhecida como a fase de indução, onde, após a apresentação dos antígenos, as células T sofrem ativação e expansão clonal no sentido CD4+ Th1, Th2 ou Th17. Logo em seguida, ocorre a segunda fase chamada de fase efetora que é marcada ou pela ativação de macrófagos (relacionada à resposta Th1) ou pela produção de anticorpos (relacionada à resposta $\mathrm{Th} 2)$.

Mais especificamente, a diferenciação das respostas Th1/Th2 durante a fase de indução é dependente do tipo de citocinas produzidas pelas células Th durante a expansão clonal. A IL-4, sintetizada por estas células, por exemplo, regula de maneira autócrina a ativação e a expansão clonal das células T CD4 ${ }^{+}$, deslocando a resposta imune para a via Th2. Esta via é marcada pela produção de outras citocinas como IL-5, IL-10, IL-13 e TGF- $\beta$, que atuam inibindo a via Th1. Adicionalmente a IL-4 produzidas pelas células Th2 CD4+ favorece a diferenciação dos linfócitos B em plasmócitos produtores de anticorpos ou células B de memória.

Quando a célula T CD4+ é estimulada a produzir IL-12, a resposta imune é polarizada no sentido Th1. Este padrão de resposta é caracterizado pela produção de INF-g e a ativação da resposta efetora celular mediada por macrófagos que, uma vez ativados por essa via, se tornam verdadeiras fábricas produtoras de citocinas pró-inflamatórias como a IL-1, IL-6 e TNF- $\alpha$. Além dessas citocinas, o 
macrófago ativado também pode produzir IL-12, estimulando assim a manutenção do ciclo de ativação da via Th1.

O sistema imunitário adaptativo é importante para a manutenção da homeostase e para o desenvolvimento da resposta imune efetiva contra os agentes patogênicos. Acredita-se, contudo, que o desequilíbrio dessa resposta possa estar envolvido na patogênese das doenças inflamatórias intestinais (DIIs), como a doença de Crohn e a Colite Ulcerativa.

Sugere-se, com base em estudos em humanos e animais, que as vias Th1 ou Th2 da resposta imune participam em fases distintas da patogenia da Doença de Crohn. No modelo experimental dessa doença, em ratos, a expressão de TNF- $\alpha$ e INF-g, citocinas típicas da via Th1, estão aumentadas na fase aguda da doença. No entanto, o estabelecimento da doença crônica passa a ser mediado por IL-5 e IL-13, citocinas comuns a via Th2.

Analisando essas doenças, pode-se considerar que as respostas imunes Th1/ Th2 já não representam adequadamente a complexidade das respostas imunes. Neste contexto, estudos mais recentes têm demonstrado o envolvimento da via Th17 nos processos fisiopatológicos das DIIs.

A ativação e diferenciação das células T naïve em células Th17 é dependente principalmente da regulação estabelecida pelas citocinas TGF- $\beta$ (Fator de Crescimento Transformador- $\beta$ ) e IL-6. A presença da IL-6 é determinante para o desenvolvimento da via Th17, uma vez que, a ausência dessa citocina proporciona a diferenciação das células T naïve em outra subfamília importante de células $T$, as células Treg. Além disso, nos processos inflamatórios crônicos do TGI a IL23 desempenha um papel pivô na ativação e diferenciação das Th17, formando o braço IL-23/Th17 importante para o entendimento da fisiopatologia da DIIs (Maloy, 2008). Uma vez ativadas, as células Th17 produzem várias citocinas com atividade pró-inflamatória IL-6, IL-17, IL-21, IL-22, IL-26 e TNF- $\alpha$.

Em estudos experimentais de colite dependente de células T, a utilização de animais knockout para IL-23 ou anticorpos monoclonais específicos para a subunidade IL-23p19 atenuou significativamente o processo inflamatório e os sinais da doença. Além disso, a inibição da IL-23 também evitou o desenvolvimento da colite espontânea em camundongos knockout para IL- 10 .

Ao dosar as concentrações de IL-23 nos tecidos, foi constatado que, na colite experimental, os níveis de IL-23 estão aumentados no intestino inflamado, mas não em tecidos sistêmicos como o baço e o fígado. Em outro experimento, foi evidenciado que a resposta imunológica sistêmica não foi inibida na ausência de IL-23, mas em vez disso, mostrou-se dependente de IL-12 (citocina relaciona a via Th1) (MALOY, 2008). Contudo, curiosamente a depleção de IL-12 não influenciou o desenvolvimento da imunidade adquirida mediada por células T na inflamação intestinal. 
Estes achados sugerem que a IL-23 e a IL-12 podem desempenhar papeis diferentes na resposta imune local, mais especificamente nas mucosas intestinais, ou na imunidade sistêmica. A depleção seletiva de IL-23 pode inibir a inflamação intestinal sem interferir na resposta imune sistêmica enquanto que, a IL-12 desempenha o papel inverso ao da IL-23, sendo mais importante para a imunidade sistêmica, sem interferir diretamente na imunidade da mucosa intestinal (MALOY, 2008).

Além disso, já foi demonstrado que a IL-23 participa da patogenia das DIIs em humanos. Vários estudos identificaram polimorfismos de nucleotídeo único no locus do gene IL-23R que foram associados com qualquer susceptibilidade ou resistência as DIIs.

Desta forma, fica evidente que as vias de regulação da imunidade adaptativa desempenham um papel dual nos processos de saúde/doença. Sendo assim, o entendimento das complexas interações e particularidades relacionadas a cada condição patológica, parece ser o melhor caminho para o desenvolvimento de protocolos terapêuticos mais eficientes.

A Figura 29.2 resume os processos de reconhecimento de antígenos, ativação de células dendríticas e polarização de linfócitos T.

\subsection{EFETORES NA RESPOSTA INFLAMATÓRIA}

\subsubsection{IMUNOGLOBULINAS}

As imunoglobulinas são moléculas glicoproteicas secretadas por plasmócitos em resposta a imunógenos, e desempenham a importante função de anticorpos sendo responsáveis pelo reconhecimento e neutralização de antígenos. Podem ser subdivididas em cinco classes: IgA, IgD, IgE, IgG, IgM.

No intestino, como mencionado anteriormente neste capítulo, o tecido linfoide associado à mucosa é representado pelas placas de Peyer, que são recobertas por células epiteliais especializadas, as células M (Células microfold). Estas células são capazes de endocitar antígenos do lúmen intestinal e transportá-los através de vesículas de transcitose até os folículos subjacentes. Estes folículos são ricos em células dendríticas capazes de processar o antígeno e apresentá-lo as células $\mathrm{T}$, dando inicio a uma resposta $\mathrm{T} \mathrm{CD}^{+}{ }^{+}$com ativação de células $\mathrm{B}$ e consequente produção seletiva de imunoglobulinas IgA (Figura 29.2).

A IgA existe em duas formas- a monomérica e a dimérica. A IgA dimérica é o anticorpo predominante nas secreções do TGI e, por isso, é considerada 
responsável pela regulação e ativação das defesas das mucosas. A IgA dimérica é formada a partir da união de duas moléculas de IgA monoméricas. Sua produção é mediada pelos plasmócitos localizados na lâmina própria da mucosa e, apesar de ser uma proteína, a IgA presente nas secreções no lúmen é bastante resistente a degradação proteolítica das enzimas gástricas e intestinais.

O processo de transporte e secreção dessa imunoglobulina dos plasmócitos localizados na lâmina própria da mucosa até o lúmen intestinal ocorre através da ligação a receptores poliméricos para imunoglobulinas (pIgR), expressos na camada basal das células epiteliais da mucosa. Após a ligação, o complexo formado é endocitado pela célula epitelial e transportado por transcitose para a porção apical da membrana celular, onde então é liberado no lúmen com o fragmento extracelular do receptor, chamado de componente secretor (CS), formando assim a $\operatorname{Ig} \mathrm{A}$ secretora $(\operatorname{sig} \mathrm{A})$.

A IgA, assim que liberada pelos plasmócitos, ainda na lâmina própria da mucosa, pode capturar antígenos que tenham ultrapassado a barreira epitelial. Estes antígenos, uma vez ligados, são transportados junto a IgA, atravessam a barreira epitelial e são deportados para o lúmen. Durante a passagem pelo citoplasma, a IgA pode interagir com moléculas virais, impedindo a sua replicação no interior das células epiteliais infectadas (LAMM, 1998).

No lúmen, a sIgA tem a capacidade de ligar-se inespecificamente a antígenos da superfície mucosa. Este efeito neutraliza a ação do antígeno impedindo a penetração e a aderência deste na camada epitelial da mucosa. A sIgA possui afinidade não-específica com mucinas secretadas pela mucosa intestinal e a formação do complexo antígeno-sIgA aumenta a retenção de micro-organismos patogênicos ao muco e estimula sua secreção, facilitando a degradação enzimática e a eliminação do antígeno sem haver a necessidade de ativar a resposta inflamatória (CAMPOS, 2011) (Figura 29.2).

A IgM também é encontrada nas secreções do TGI e denota ação muito semelhante a realizada pela IgA com relação à neutralização de antígenos. A IgM é a primeira imunoglobulina a ser produzida pelo plasmócito ativado e acredita-se que no TGI, tanto a IgA como a IgM, seriam mediadores não-inflamatórios cuja a função primordial consistiria na manutenção da homeostase local e da benéfica relação com os micro-organismos comensais. Inclusive, as moléculas de $\operatorname{IgA}$ e IgM poliméricas possuem a capacidade de estimular a produção de IL-10 e inibir a produção de IL-2 e a ativação do NF- $\mathrm{B}$, reduzindo significativamente a produção de mediadores inflamatórios.

Quando, contudo, um antígeno ultrapassa os limites impostos pela $\operatorname{IgA}$ rapidamente o organismo responde, aumentando a produção de IgG. Esta 
imunoglobulina, que compõe a segunda linha de defesa da mucosa do TGI, é capaz de iniciar uma forte resposta inflamatória.

A ação pró-inflamatória mediada pela IgG inicia-se com a opsonização do antígeno, que terá sua superfície totalmente recoberta. Este efeito neutraliza a ação do antígeno impedindo a aderência e penetração deste na camada epitelial da mucosa. Além disso, a opsonização do antígeno facilita a ação de células dendríticas e macrófagos, que fagocitam o antígeno e apresentam os epítopos às células $T$ auxiliares (Th $-\mathrm{T}$ helper) via $\mathrm{CD} 4^{+}$. A ativação destas células acaba produzindo respostas do tipo Th1, com consequente produção de citocinas pró-inflamatórias (TNF- $\alpha$, IL-1, IL-6), e do tipo Th2, com a produção de outras imunoglobulinas como IgA, IgM, IgE e IgG. Além disso, a IgG pode ativar, a partir da ligação com a $\operatorname{IgA}$, a cascata de ativação do sistema complemento levando à destruição dos micro-organismos por meio da lise de suas membranas.

Outro anticorpo fisiologicamente importante para a manutenção das defesas da mucosa gástrica é a IgE. A resposta dessa imunoglobulina tem sido fortemente associada com infecções parasitárias e doenças alérgicas. Em camundongos infectados com o parasita intestinal Trichinella spiralis, a IgE é transferida diretamente para o local da infecção onde inicia a resposta contra o nematóide, que resulta na rápida eliminação do parasito intestinal.

A proporção de IgE presente no lúmen do animal infectado pode ser até $50 \%$ maior que no animal não parasitado. No duodeno, a diferença pode ser de até $86 \%$. Sabe-se que a IgE é capaz de atravessar a barreira epitelial da mucosa, porém o mecanismo de transporte ainda não esta completamente elucidado. Entretanto, demonstrou-se que o aumento da produção de interleucina 4 (IL-4), produzida por células T CD4+ Th2 em uma infecção por parasitas, afeta o transporte seletivo de IgE para lúmen intestinal.

A IgE regula a ação contra os parasitas mediante a ativação celular de mastócitos e eosinófilos através da interação com receptores de alta afinidade para IgE, os FceRI. Esta interação induz a degranulação celular, resultando na liberação de mediadores pré-formados, como histamina, heparina, proteases e TNF- $\alpha$, que irão desencadear a resposta inflamatória. Estes mediadores pré-formados são importantes para a defesa dos organismos, mas também contribuem para o desenvolvimento de processos fisiopatológicos observados em reações alérgicas a alimentos.

Além disso, a IgE também pode interagir com neutrófilos, macrófagos, células dendríticas e enterócitos. Nos enterócitos, a ligação ocorre através dos receptores $\varepsilon$ BP (proteína ligadora épsilon), mas as funções dessas células mediante a interação com a IgE, ainda não está bem estabelecida. 


\subsubsection{NEUTRÓFILOS}

Os neutrófilos consistem na maior população de células imunes do organismo. Participam da fase inicial da resposta imune, sendo as primeiras células, oriundas da circulação, a chegar ao local do dano. No TGI, essas células atacam e destroem micro-organismos que romperam a barreira epitelial e entraram nos tecidos ou na circulação. Para que essas células possam realizar, porém, a sua importante função imune, é necessário que ocorra uma sequência de eventos que incluem o recrutamento ativo de neutrófilos para o local da lesão seguido do reconhecimento, ingestão e destruição dos micro-organismos por fagocitose (ABBAS, 2008).

\subsubsection{RECRUTAMENTO DE NEUTRÓFILOS}

O recrutamento dessas células para o local da lesão é rápido, mas envolve múltiplas etapas, como a fixação dos leucócitos circulantes à superfície endotelial das vênulas pós-capilares e a migração dessas células pela parede do vaso. Cada etapa é orquestrada por vários tipos diferentes de moléculas (ABBAS, 2008).

A partir do contato com micro-organismos patogênicos, as células epiteliais e as células residentes (células dendríticas, macrófagos, mastócitos) iniciam a produção de quimiocinas (moléculas capazes de atrair os neutrófilos) e citocinas (IL-1, TNF- $\alpha$ ). A ação das quimiocinas associado à vasodilatação e diminuição do fluxo sanguíneo local facilita a aproximação dos neutrófilos à margem dos vasos sanguíneos.

Além disso, o contato das citocinas IL-1 e TNF- $\alpha$ com receptores específcos localizados nas células endoteliais dos vasos, próximos ao local da infecção, induzem a ativação de mecanismos intracelulares que aumentam a expressão de moléculas de rolamento chamadas selectinas.

Os dois tipos de selectinas mais expressos nas células endoteliais são a P e E selectinas. A selectina $\mathrm{P}$ está pronta e armazenada em grânulos citoplasmáticos, chamados corpúsculos de Weibel-Palade. Por isso são rapidamente expostas na superfície da membrana plasmática da célula endotelial após o estímulo das citocinas IL-1 e TNF- $\alpha$. Já a selectina E, apenas será sintetizada pela célula endotelial após o estímulo das citocinas, sendo expressa na superfície da membrana citoplasmática somente após 1 a 2 horas do estímulo. Existe ainda uma terceira molécula de rolamento conhecida como selectina L, presente nos neutrófilos. Esta selectina auxilia no processo de rolamento dos neutrófilos sobre as células endoteliais ativadas (ABBAS, 2008).

Além disso, a ligação dos neutrófilos às células endoteliais depende das interações de baixa afinidade $(\mathrm{Kd} \sim 100 \mathrm{mM})$ das selectinas com os carboidratos 
ligantes de selectinas (Sialil Lewis X). Essas ligações de baixa afinidade são facilmente rompidas pela força de cisalhamento do fluxo sanguíneo que empurra os neutrófilos forçando a interação com outras selectinas. Logo, em virtude da natureza dessas interações, os neutrófilos repetitivamente se destacam e se ligam novamente as selectinas e assim "rolam" ao longo da superfície endotelial.

Quando os neutrófilos se aproximam do local da infecção, as quimiocinas presentes em maior concentração se ligam a receptores específicos na superfície dos neutrófilos em rolamento e estimulam a expressão de moléculas de adesão mais fortes, chamadas de integrinas (VLA-4, LFA-1 e Mac-1). Em paralelo com a ativação das integrinas nos neutrófilos, as citocinas IL- 1 , TNF- $\alpha$ e INF- $\gamma$ também aumentam a expressão de ligantes das integrinas nas células do endotélio vascular. Dentre estas moléculas ligantes, estão à molécula de adesão de células vasculares - 1 (VCAM-1) que se liga a integrina VLA-4 (Very Late Antigen-4, CD49d/ CD29) do neutrófilo, a molécula de adesão intercelular - 1 (ICAM-1) ligante das integrinas LFA-1 (Antígeno associado à função leucocitária) e Mac-1 (CD11b/ CD18). Como resultado dessas novas interações, os neutrófilos fixam-se firmemente ao endotélio vascular.

Após a adesão firme dos neutrófilos é iniciado o processo de transmigração dessas células através do endotélio. Esse fenômeno ocorre mediante a ação atraente cada vez mais forte das quimiocinas que, em favor de um gradiente de concentração química, atraem os neutrófilos na direção do local da infecção. Com o auxílio de proteases lisossomais, os neutrófilos lesam a membrana basal da parede vascular chegando ao interstício, em um fenômeno conhecido como diapedese. Ao final desse processo, os neutrófilos se acumulam no tecido extravascular em torno do agente infeccioso, onde iniciam a fagocitose.

\subsubsection{FAGOCITOSE E DESTRUIÇÃO DOS MICRO-ORGANISMOS INVASORES}

Os neutrófilos são células especializadas em englobar grandes partículas por via de um processo ativo conhecido como fagocitose. Esse processo é iniciado via receptores de reconhecimento de padrões dos neutrófilos (ABBAS, 2008). Além desses, existem outros receptores especializados no reconhecimento de proteínas endógenas que marcam micro-organismos para fagocitose. Essas proteínas são chamadas de opsoninas e incluem anticorpos, o C3b do sistema complemento e as lectinas. Logo, o processo de marcar um patógeno para torná-lo um alvo para a fagocitose é chamado de opsonização.

A ligação de receptores específicos, nos neutrófilos, a um patógeno ou a uma opsonina, induz modificações na membrana plasmática dessas células. Es- 
sas modificações consistem na projeção da membrana em direção ao antígeno, formando uma concavidade em torno do alvo. Quando a concavidade engloba completamente o antígeno, ela se fecha formando uma vesícula chamada de fagossomo.

Os neutrófilos contêm vesículas repletas de enzimas proteolíticas e espécies reativas do oxigênio (ROS) conhecidas como lisossomos. Após a fagocitose, ocorre no interior dos neutrófilos a fusão do fagossomo com o lisossomo resultando na formação da unidade da digestão de antígenos, onde todos os mecanismos microbicidas são concentrados, o fagolisossomo (ABBAS, 2008).

\subsubsection{PARTICIPAÇÃO DOS NEUTRÓFILOS E SEUS PRODUTOS NOS MECANISMOS FISIOPATOLÓGICOS}

Quando os neutrófilos são fortemente ativados, os produtos microbicidas não distinguem micro-organismos de tecidos próprios. Como resultado, quando esses produtos entram no ambiente extracelular são capazes de causar a lesão tecidual (ABBAS, 2008). Esse mecanismo contribui diretamente para o desenvolvimento de diversas doenças.

Os lisossomos dos neutrófilos estocam uma grande variedade de serino proteases, incluindo elastases, catepsinas G, e proteinases 3. Essas enzimas atuam predominantemente no fagolisossomo para destruir os micro-organismos fagocitados.

Há evidências de que, durante episódios inflamatórios comuns às DIIs, um grande número de neutrófilos infiltra na lâmina própria da mucosa intestinal. Esse aumento do infiltrado inflamatório é acompanhado por intensos danos à mucosa, aumento da permeabilidade, destruição da matriz extracelular, edema, erosão das células epiteliais e formação de úlceras. Esses efeitos deletérios são causados devido à ação direta dessas proteases na lâmina própria da mucosa que é a estrutura de suporte para o epitélio e para as vilosidades intestinais. Logo a infiltração de neutrófilos nesta região pode contribuir diretamente para a fisiopatologia das DIIs.

As serino proteases dos lisossomos dos neutrófilos podem ainda participar da resposta inflamatória ativando citocinas e fatores de crescimento. A proteinase 3 pode ativar a liberação de TNF- $\alpha$, IL-1 $\beta$, e IL8. A elastase pode ativar o receptor do fator de crescimento epidermal (EGFR), via liberação do seu ligante o EGF, e possivelmente o TLR-4, e a catepsina G pode ativar o receptor ativado por protease-4 (PAR4).

Além disso, os neutrófilos são ricos em ROS cuja ação bactericida pode provocar danos às células. A fonte predominante de ROS é o nicotinamida-adenina-dinucleotideo-fosfato oxidase (NADPH), que produz o ânion superóxido (O2-). 
Esse radical livre altamente reativo interage com outras moléculas para produzir radicais livres com ação oxidante, como o peroxido de hidrogênio $\left(\mathrm{H}_{2} \mathrm{O}_{2}\right)$, o ácido hipocloroso $(\mathrm{HClO})$ e o radical hidroxila $\left(\mathrm{OH}^{-}\right)$. Quando as ROS superam as defesas antioxidantes da célula como a superóxido dismutase, catalase, glutationa peroxidase e a glutationa (GSH), os danos aos tecidos ocorrem. Inclusive a redução do estresse oxidativo sob estas condições pode ser um potencial alvo terapêutico para as doenças inflamatórias do intestino, particularmente a DIIs e a enterite provocada pela radiação.

\subsubsection{EICOSANOIDES}

Os eicosanoides são substâncias derivadas do ácido aracdônico liberado a partir do metabolismo de fosfolipídeos de membrana. O metabolismo do ácido aracdônico é realizado por duas classes de enzimas: as cicloxigenases e as lipoxigenases.

As cicloxigenases apresentam três isoformas principais denominadas cicloxigenase-1 (COX-1), -2 (COX-2) ou -3 (COX-3). A COX-1 é uma isoforma constitutiva e presente na maioria das células. A COX-2 é uma isoforma da enzima predominantemente induzível durante respostas inflamatórias, estando presente em vários tipos de células e tecidos e cuja expressão depende da sinalização de citocinas como o TNF e a IL-1. Já a COX-3, uma isoforma variante da COX-1 descoberta no início dos anos 2000 cuja participação nos processos fisiológicos e patológicos ainda não está bem estabelecida.

As COXs são enzimas responsáveis pela produção de prostaglandinas (PGI2, PGE2, PGF2 e PGD2) e tromboxanos (TXA2 e TXB2) enquanto que as lipoxigenases são responsáveis pela produção de Leucotrienos.

As prostaglandinas formadas pelas COXs desempenham múltiplas funções, tanto na regulação da homeostase como também na patogenia das DIIs. Até pouco tempo, acreditava-se que os produtos relacionados à atividade da COX-1 estavam envolvidos somente na regulação da homeostase, enquanto, as prostaglandinas produzidas pela COX-2 participavam exclusivamente dos processos inflamatórios. Esse conceito, no entanto, esta sendo questionado, pois é demonstrado que a COX-1 participa de processos inflamatórios gastrintestinais e que a inibição da COX-2 pode participar do processo de fechamento de úlceras ativas e regular o fluxo sanguíneo vascular e renal.

As prostaglandinas no TGI modulam os componentes de defesa da mucosa como a secreção de muco e bicarbonato, aumentam o fluxo sanguíneo e a resistência das células epiteliais a lesões provocadas por citotoxinas, além de suprimir o recrutamento de neutrófilos para a mucosa. A prostaglandina E2, por exemplo, demonstrou ser um potente inibidor da liberação de TNF- $\alpha$ e IL-1 por 
macrófagos. Essas ações contribuem para o efeito protetor das prostaglandinas nas mucosas do TGI. Vários trabalhos confirmam o papel protetor da PGE2, contra a lesão gástrica induzida por etanol e na lesão duodenal induzida por indometacina. $\mathrm{O}$ mesmo papel protetor foi observado no modelo experimental de colite ulcerativa induzida com dextrana sulfato de sódio (DSS) em camundongos e ratos, e a utilização de animais knockout para os receptores de prostaglandina EP3 e EP4 confirmou esses achados.

Os tramboxanos durante o processo inflamatório aumentam a agregação plaquetária e a vasoconstrição, facilitando a formação de trombos. Esses compostos possuem meia-vida muito curta e são rapidamente convertidos a sua forma inativa. Entretanto, esses elementos podem contribuir significativamente para a inflamação intestinal, uma vez que, a utilização de antagonistas específicos para os receptores de tramboxano A2 inibiram o desenvolvimento da resposta inflamatória no modelo experimental de colite.

Os leucotrienos são produtos da via das lipoxigenases. A principal enzima dessa classe é a 5-lipoxigenase cuja atividade sobre o ácido aracdônico resulta na produção do leucotrieno A4, que, por sua vez, pode ser convertido em leucotrieno B4 (LTB4) ou em uma série de moléculas contendo aminoácidos cisteína incorporados a sua estrutura chamados de cisteinil-leucotrienos (LTC4, LTD4, LTE4, LTF4). O LTB4 é um potente agente quimiotático para neutrófilos, eosinófilos e monócitos, estimula a proliferação de macrófagos e linfócitos e a produção de citocinas por essas células, podendo estar envolvido na fisiopatologia da inflamação aguda intestinal. Entretanto, ainda existem poucas evidências acerca do real envolvimento dos leucotrienos nas doenças inflamatórias intestinais.

\subsection{4 ÓXIDO NÍTRICO}

O óxido nítrico (NO) é um radical livre gasoso formado da reação catalisada pela enzima oxido nítrico sintase (NOS) que converte a L-Arginina e oxigênio molecular $\left(\mathrm{O}_{2}\right)$, em NO e L-Citrulina. Três isoformas da NOS já foram descritas. Duas delas, a neuronal (nNOS ou NOS1) e a endotelial (eNOS ou NOS3) são expressas constitutivamente nos tecidos onde produzem NO em concentrações picomolares numa reação dependente do $\mathrm{Ca}^{++}$intracelular para ocorrer. A terceira isoforma é a forma induzível da NOS (iNOS ou NOS2) e sua expressão é modulada por mediadores inflamatórios. A iNOS é capaz de produzir concentrações micromolares de $\mathrm{NO}$ em um meio independente de $\mathrm{Ca}^{++}$superando a produção de NO das NOS constitutivas.

O papel do NO nas defesas da mucosa é controverso, e não se sabe ao certo se prevalecem os efeitos benéficos ou maléficos. Nesses tecidos, o NO pode 
auxiliar na manutenção do suprimento sanguíneo da mucosa gastrintestinal durante o período de exposição a um dano na mucosa, o que é vital para a recuperação do tecido. Além da melhora no fluxo sanguíneo, as ações protetoras do NO podem envolver uma ação microbicida direta, diminuição da aderência de leucócitos ao endotélio, inibição da ativação de mastócitos e a produção de citocinas da via Th1.

Contudo, quando produzido em grandes quantidades o NO pode ter o efeito deletério. Nas DIIs as células epiteliais expressão iNOS, essas enzimas são capazes de produzir grandes quantidades de NO (micromolar) durante longos períodos. Grandes concentrações de NO na mucosa aumentam a permeabilidade da barreira e facilitam a entrada de micro-organismos desencadeando uma cascata de eventos inflamatórios. Somado a isso, o $\mathrm{NO}$ pode reagir com o superóxido $\left(\mathrm{O}^{2-}\right)$ formando o peroxinitrito $\left(\mathrm{OONO}^{-}\right)$um poderoso radical com alto potencial citotóxico que pode contribuir para o aumento das lesões nos tecidos.

Apesar do extenso conflito de dados acerca da atividade pró-inflamatória ou anti-inflamatória do NO, sabe-se que a produção excessiva e prolongada de NO pode ser uma das causas da disfunção intestinal comum a DII. Contudo, considerando o papel fisiológico do NO, a inibição de sua produção pode produzir efeitos colaterais superiores aos efeitos terapêuticos.

Desta forma, ainda é muito cedo para se pensar no NO como um alvo terapêutico para o tratamento das doenças inflamatórias intestinais, justamente devido a ambiguidade de suas funções, pró e anti-inflamatórias, cujos limites ainda não estão bem determinados dentro dos processos de saúde e doença.

\subsection{RESOLUČ̃̃ OU CRONIFICAC̣ÃO DO PROCESSO INFLAMATORIO}

\subsubsection{RESOLUÇÃO DO PROCESSO INFLAMATÓRIO}

A resolução ou restauração da normalidade dos tecidos após a inflamação aguda não é simplesmente um evento passivo provocado pela supressão ou eliminação do agente patogênico iniciador do estímulo inflamatório. Na verdade, a transição entre a inflamação e a cura se trata de um processo ativo caracterizado pela síntese de componentes da resposta imune com propriedades anti-inflamatórias.

De fato, para que haja a resolução do processo inflamatório, é necessário o estabelecimento de um novo equilíbrio da resposta imune onde os componentes anti-inflamatórios prevaleçam sobre os pró-inflamatórios. Isto inclui a ação da 
IL-10, prostaglandinas, particularmente a $\mathrm{PGJ}_{2}$, lipoxinas, resolvinas, anexina-1, além dos receptores solúveis para TNF- $\alpha$ e IL-1 entre outros fatores.

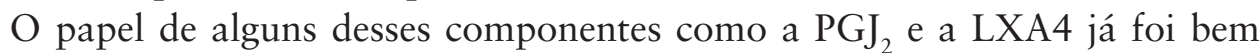
estabelecidos na literatura. No modelo experimental de colite em ratos, a administração de $\mathrm{PGJ}_{2}$ atenuou a resposta inflamatória mediante a ligação ao receptor ativado por proliferador de peroxissomo $-\gamma(\operatorname{PPAR}-\gamma)$ desencadeando uma rea-

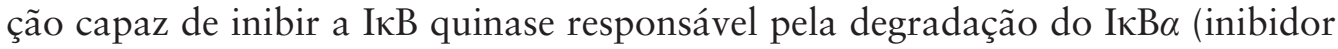

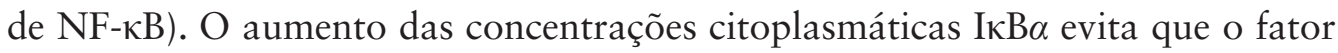

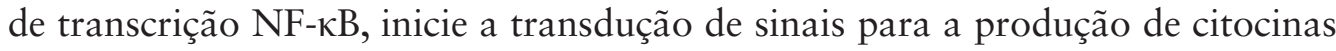
pró-inflamatórias.

A lipoxina A4 (LXA4), um metabólito derivado do ácido araquidônico. É formada a partir da atividade da 5-lipoxigenase presente nas plaquetas e nas células epiteliais e, curiosamente, também pode ser formada após a ligação da aspirina a COX-2 (15-epi-LXA4). O efeito anti-inflamatório da LXA4 consiste na inibição da produção de TNF- $\alpha$ e IL-8 na mucosa intestinal humana. Além disso, a LXA4 pode inibir o rolamento e a adesão de neutrófilos no endotélio vascular, como também podem inibir a migração de polimorfonucleares através da monocamada epitelial.

Quando os elementos da resposta imune aguda falham na eliminação do agente agressor, tanto o agente agressor quanto os produtos da lesão tecidual são capazes de estimular a resposta inflamatória. Com isso, ao longo do tempo, mudanças no perfil inflamatório passaram a caracterizar o processo crônico da resposta imune.

\subsubsection{INFLAMAÇÃO CRÔNICA}

A falha na eliminação do agente agressor, assim como à produção exacerbada de mediadores pró-inflamatórios direcionam o prolongamento da resposta inflamatória, tornando o processo inflamatório crônico.

A passagem da fase aguda para crônica ainda não está bem definida. Contudo, pode-se levar em consideração que no processo de transição essa passagem acontece de forma gradual. Portanto, sempre haverá um período em que os elementos de ambas as fases se misturam, e o infiltrado inflamatório passa a ser constituído tanto por neutrófilos da fase aguda, quanto por macrófagos, linfócitos e plasmócitos que anunciam o início da fase crônica, embora cronologicamente ainda seja impossível determinar qual o momento exato da transição da fase aguda para a fase crônica. É possível identificar as mudanças no padrão dos mediadores atuantes nas diferentes fases. Há evidencias de que na inflamação intestinal, os mediadores na fase aguda e crônica sejam bastante diferentes e que 
os mecanismos iniciadores da doença não sejam os mesmos responsáveis pela manutenção ou reagudização do processo patológico crônico.

$\mathrm{Na}$ fase crônica do processo inflamatório, as células comumente envolvidas são macrófagos e linfócitos, particularmente T CD4+ que desempenham um papel central na geração de citocinas específicas que perpetuam o processo inflamatório e o remodelamento tecidual.

Além disso, durante a inflamação intestinal crônica, uma manifestação comumente observada na doença de Crohn consiste no aumento da fibrose das camadas submucosa e muscular do intestino, prejudicando as funções normais do órgão. Acredita-se que o aumento no número de fibroblastos e da deposição de colágeno, fibrina na região afetada, esteja associado ao efeito do fator de crescimento TGF- $\beta$.

Outra citocina com reconhecida participação na inflamação crônica é a IL-18. Essa citocina possui papéis diferenciados na fase aguda e crônica da inflamação intestinal. $\mathrm{Na}$ fase aguda a IL-18, produzida por células epiteliais, reduz a produção de citocinas pró-inflamatórias. Entretanto, curiosamente em modelos de doença intestinal crônica como na doença de Crohn, a IL-18, produzida por macrófagos e células dendríticas, promove a ativação da via Th1, pró-inflamatória, da reposta imune.

A maioria das doenças inflamatórias intestinais é crônica e elas não possuem cura, apenas tratamento paliativo. Desta forma, é importante considerar as particularidades entre as diferentes fases do processo inflamatório e as características de cada doença para que se possa diagnosticar e realizar a abordagem terapêutica mais adequada.

\subsection{A RESPOSTA INFLAMATÓRIA NO CONTEXTO DE DOENÇAS INTESTINAIS}

A superfície mucosa do intestino é recoberta por enormes quantidades de antígenos. Quando ocorre uma falha nos mecanismos de tolerância, o equilíbrio entre o tecido linfóide e os micro-organismos é desfeito. O simples contato desses micro-organismos com a mucosa ativa uma resposta imune muitas vezes inapropriada, levando à destruição dos tecidos e o estabelecimento das doenças inflamatórias intestinais (DIIs). As DIIs compreendem dois tipos de desordens intestinais crônicas: a doença de crohn e a colite ulcerativa. Nos últimos anos, essas doenças têm sido intensamente estudadas e muitos avanços têm permitido o entendimento de alguns aspectos das suas etiologias. 


\subsection{DOENÇA DE CROHN}

A doença de Crohn é uma doença inflamatória granulomatosa crônica do TGI, que acomete, sobretudo, o íleo ou o cólon, mas que pode também envolver qualquer outro segmento do canal alimentar desde a boca até o ânus. Os principais sintomas envolvidos são: cólica abdominal, diarreia, sangramento retal, febre, falta de apetite e consequente perda de peso. $\mathrm{Na}$ fase crônica da doença, podem ocorrer perfuração, fistulização e formação de tecido fibroso que pode levar à obstrução intestinal. Além das manifestações no TGI, a doença de Crohn é frequentemente acompanhada por manifestações extraintestinais, como uveíte, artrite e lesões cutâneas.

Apesar da etiologia da doença de Crohn ainda não estar bem esclarecida, várias evidências sugerem a participação direta de componentes da resposta imune inata e adaptativa influenciados por fatores ambientais e genéticos. Os medicamentos utilizados para o tratamento dessa doença atualmente têm contribuído para amenizar a inflamação e habitualmente proporcionam o controle dos sintomas. Contudo, ainda não há cura efetiva.

\subsubsection{EPIDEMIOLOGIA DA DOENÇA DE CROHN}

A doença de Crohn geralmente manifesta-se em indivíduos jovens. A média de idade onde a incidência da doença é mais frequente varia entre 15 e 40 anos. Sendo que, 25 a $35 \%$ dos pacientes são diagnosticados antes dos 20 anos de idade. Além disso, não existe diferença na incidência entre os sexos.

Nos países desenvolvidos, a cada 100.000 habitantes três a 20 indivíduos são diagnosticados com a doença de Crohn (PEPPERCORN, 2013). Na Europa a cada 100.000 habitantes 5,9 sofrem com a doença de Crohn, nos Estados Unidos esse número chega a 11,2 a cada 100.000 habitantes. No Brasil ainda não há estudos que registrem a prevalência da doença de Crohn, mas estima-se que seja bastante elevada. Segundo o Ministério da Saúde (2010), a prevalência da doença de Crohn na cidade de São Paulo - SP seria de 14,8 casos a cada 100.000 habitantes.

\subsubsection{ASPECTOS CLÍNICOS DA DOENÇA DE CROHN}

Os pacientes com doença de Crohn que buscam atendimento médico pela primeira vez, na grande maioria, são adolescentes. Desses, mais de 70\% manifestam a doença na porção terminal do íleo.

$\mathrm{Na}$ anamnese, a queixa típica desses pacientes consiste em uma história crônica com episódios recorrentes de dor no quadrante abdominal inferior direito e 
diarreia. A dor abdominal é típica na ileíte (inflamação do Íleo), por outro lado quando a doença é restrita ao cólon não é obsevada dor abdominal, mas sim uma diarreia intensa que pode ser acompanhada de sangramento e tenesmo (sensação de evacuação incompleta). Os pacientes que apresentam a doença no cólon desenvolvem complicações na região perianal. Apenas 5\% do total de pacientes com doença de Crohn apresentam a doença localizada na mucosa bucal, esôfago, estômago, duodeno e jejuno. Estes pacientes apresentam estomatite aftosa, gastrite e deficiência nutricional devido ao comprometimento da capacidade absortiva do intestino. O processo inflamatório na doença de Crohn, em longo prazo, produz uma série de complicações levando à recorrente obstrução intestinal e a formação de fístulas e abcessos, que muitas vezes são acompanhadas por manifestações extraintestinais.

O diagnóstico da doença de Crohn é considerado difícil em virtude das várias formas de manifestação ao longo do TGI e à grande semelhança com outras patologias. Devido a esta característica, para se obter um bom diagnóstico é necessária a análise conjunta de dados clínicos, endoscópicos, histológicos e radiológicos. Como resultado, identifica-se um acometimento focal, assimétrico, transmural ou granulomatoso da parede intestinal.

A sequência dos procedimentos diagnósticos deve ser estabelecida de acordo com a apresentação clínica de cada paciente e gravidade da doença. Nos exames radiológicos contrastados, por exemplo, é possível detectar a presença de fístulas no intestino delgado. A endoscopia, por sua vez, permite a visualização direta das lesões ulceradas, acompanhadas por áreas com mucosa normal. A distribuição dessas lesões pode ser focais, assimétricas ou descontínuas. Além disso, através da endoscopia é possível coletar material para análise histopatológica. A análise histológica pode indicar acometimento transmural, em decorrência do padrão segmentar e presença de granulomas não caseosos, que, apesar de serem considerados patognomônicos, estão em menos de $50 \%$ dos casos.

O conjunto de achados nos exames complementares, associados aos dados obtidos na anamnese, permite classificar a gravidade da doença em leve, moderada ou grave de acordo com o índice de atividade da doença de Crohn (IADC) (Quadro 29.1). A correta classificação da doença é determinante para o estabelecimento do protocolo terapêutico mais adequado. A doença é considerada em remissão (sem atividade da doença após tratamento) quando o IADC é inferior a 150; leve a moderada quando o IADC oscila entre 150 e 219; moderada a grave os valores ficam em torno de 220 a 450, e grave ou fulminante quando os valores são superiores a 450 . 
Quadro 29.1 - Índice de atividade da doença de Crohn (IACD).

\begin{tabular}{|c|c|}
\hline Número de evacuacõoes líquidas e pastosas * & $\times 2$ \\
\hline Dor abdominal (nenhuma $=0$, leve $=1$, moderada $=2$, intensa $=3$ ) * & $\times 5$ \\
\hline Sensação de bem-estar (bem $=0$, desconfortável $=1$, ruim $=2$, péssimo $=3$, terrível $=4$ ) * & $\times 7$ \\
\hline $\begin{array}{l}\text { Número de complicações (artrite/artralgia, irite/uveíte, eritema nodoso/pioderma gangrenoso ou } \\
\text { estomatite aftosa, fissura/fístula ou abscesso anal, outras fístulas, febre }>37,8^{\circ} \mathrm{C} \text { ) }\end{array}$ & $\times 20$ \\
\hline Uso de difelonato ou loperamida (não $=0, \operatorname{sim}=1$ ) & $\times 30$ \\
\hline Massa abdominal (não = 0, questionável = l, com certeza =5) & $\mathrm{x} 10$ \\
\hline Hematócrito (homens: 47 menos $\mathrm{H}+\%$; mulheres: 42 menos $\mathrm{H}+\%$ ) & $\times 6$ \\
\hline Peso (1 - peso/peso padrão x 100) adicione ou subtraia segundo o sinal & $\mathrm{x} 1$ \\
\hline Total & \\
\hline
\end{tabular}

* Médias em 7 dias (quadro retirado de: HABR-GAMA, A. et al., 2011)

\subsubsection{PATOGÊNESE DA DOENÇA DE CROHN}

Os avanços nas pesquisas acerca do mecanismo fisiopatológico da doença de Crohn sugerem que a patogênese da doença seria imunologicamente mediada através de falhas na imunidade inata e adaptativa associadas a fatores genéticos e ambientais.

\subsubsection{RESPOSTA IMUNE INATA NA DOENÇA DE CROHN}

O equilíbrio da imunidade das mucosas é dependente do bom funcionamento da imunidade inata. Os receptores de reconhecimento de padrões (PRRs) Toll-like e NOD-like presentes nas células epiteliais, células M, células de Paneth e nas células residentes (como macrófagos e células dendríticas) contribuem diretamente para a manutenção desse equilíbrio. A alteração da expressão ou a superestimulação desses receptores, por fatores genéticos ou ambientais, levam a quebra desse equilíbrio e a manifestação de doenças inflamatórias crônicas como a doença de Crohn (Figura 29.3).

Entre os PRRs, os NOD-Like do tipo NOD-1 e NOD-2 destacam-se devido a sua participação ativa na imunopatogênese da doença de Crohn. Normalmente, a ativação desses receptores pelo muramil dipepitídeo (MDP), presente na parede de bactérias Gram-positivas e Gram-negativas, desencadeia uma sequência de eventos intracelulares que culmina com a estimulação dos fatores de transcrição NF-кB e MAPK que levam ao aumento dos níveis de citocinas pró-inflamatórias, como o TNF- $\alpha$, IL-12, IL-23, IL-1 $\beta$, IL-6 e quimiocinas. Na homeostase, esses estímulos pró-inflamatórios são moderados e importantes para a manutenção do equilíbrio com a microbiota comensal (Figura 29.3). 


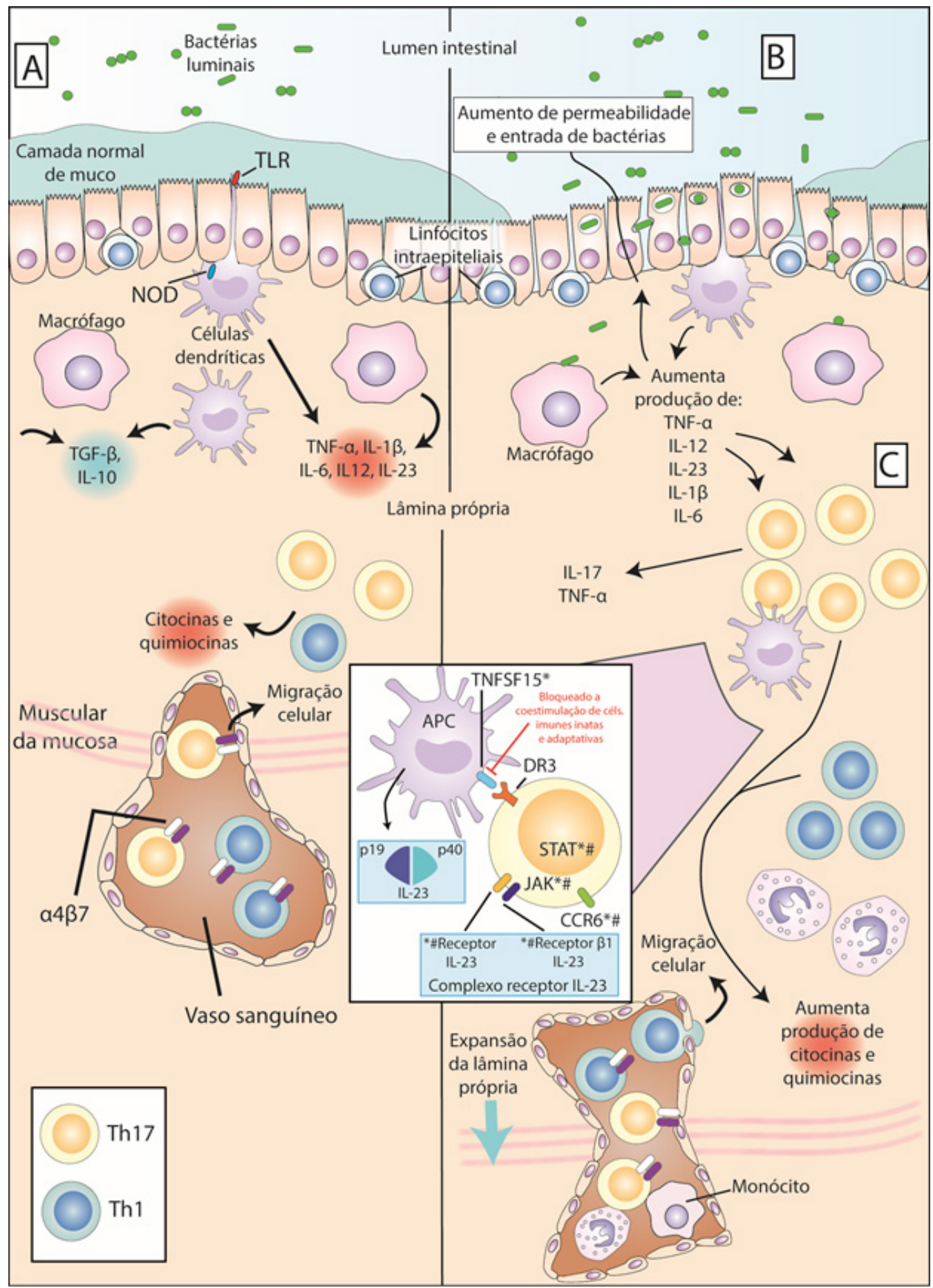

Figura 29.3 - Papel da resposta imune na saúde e na doença. 0 painel A demonstra que a equilibrada relação 
entre a microbiota e o organismo dependente do bom funcionamento da imunidade inata e adaptativa. Os receptores de reconhecimento de padrões Toll-like e NOD-like presentes nas células epiteliais e nas células residentes como macrófagos e células dendríticas auxiliam no reconhecimento dos micro-organismos. Como resultado dessa interação são produzidas citocinas em níveis adequados para estabelecer a comunicação entre essas células e 0 ajuste da resposta imune, de forma que esta permita a convivência com os micro-organismos comensais e ao mesmo tempo limite a entrada de micro-organismos patogênicos. Além disso, a interação entre as APCs (macrófagos e células dendríticas) com os linfócitos também contribui para a manutenção desse estado de equilíbrio, uma vez que, a homeostase intestinal também depende do balanço entre as células Treg (imunosupressora) e das células efetoras Thl e Th17. No painel B, pode-se observar que a alteração nos mecanismos de defesa da mucosa, como a descontinuidade da barreira epitelial ou 0 aumento da permeabilidade intestinal, aumenta a exposição aos micro-organismos e a ativação dos PRRs. Entre os PRRs, os NOD-Like do tipo NOD-1 e NOD-2 destacam-se devido a sua participação ativa na imunopatogênese da doença de Crohn. A ativação desses receptores culmina com o aumento nos níveis de citocinas pró-inflamatórias, como o TNF- $\alpha$, IL-12, IL-23, IL-1 $\beta$, IL-6 e quimiocinas. Na lamina própria há uma marcante expansão no número de células T CD4+ principalmente as pró-inflamatórias (Th1 e Th17). As células Th17 expressam na sua superfície, um complexo de receptores para IL-23, e o receptor de quimiocinas CCR6. A interleucina-23 (formada pelas subunidades $\mathrm{p} 19$ e p 40), secretada pelas células apresentadoras de antígeno (célula dendrítica), se liga ao complexo de receptores para IL-23 na célula TH17. Essa ligação resulta na ativação da quinase associada a Janus (JAK2) e ativa o fator de transcrição STAT3 (Ativador de Transcrição e Transdutor de sinal), estimulando a proliferação de células Th17, cuja ação é aumentada pelo membro 15 da superfamília do TNF (TNFSF15) ligando ao receptor de morte 3 (DR3) (painel C). A célula Th17, ao se ligar à IL-23, produz grandes quantidades de IL-17. Essa citocina via fator de transcrição NF- KB, estimula a produção de citocinas pró-inflamatórias (IL-1 $\beta$, IL-6 e TNF- $\alpha$ ), e o recrutamento de células imunes para 0 tecido intestinal. Desta forma, existem fortes indícios do envolvimento da via IL-23/Th17 na fisiopatologia da doença de Crohn (Figura adaptada de Abraham et al. 2009).

Neste sentido, polimorfismos genéticos relacionados a mutações nos genes CARD4, responsável pela codificação do receptor NOD-1, e no gene CARD15, o qual codifica o NOD-2, prejudicam as funções desses receptores e, consequentemente, a manutenção desse equilíbrio. Por isso, o polimorfismo nesses genes tem sido fortemente associado à imunopatogenia da doença de Crohn. Acredita-se que 20 a $40 \%$ dos portadores dessa doença apresentem alguma mutação no gene NOD-2/CARD15. Além disso, outros estudos demonstraram que a mutação nesses genes está fortemente ligada a forma ileal ou ileocólica estenosante da doença.

$\mathrm{Na}$ doença de Crohn, os receptores TLR-2 e TLR-4 estão suprarregulados nos macrófagos intestinais, enquanto o TLR-3 está infrarregulados. Esse padrão de expressão dos receptores Toll-like nessas células pode contribuir de alguma forma na imunopatogênese da doença de Crohn. Contudo, ainda são necessários mais estudos acerca do real papel desses receptores no mecanismo de desenvolvimento da doença. 


\subsubsection{RESPOSTA IMUNE ADAPTATIVA NA DOENÇA DE CROHN}

A doença de Crohn tem curso crônico, logo em determinado ponto de sua patogênese, componentes da resposta imune adaptativa passam a orquestrar a resposta inflamatória exagerada responsável pelos danos causados ao TGI.

A via Th1 da resposta inflamatória, mediada pelas citocinas IL-12, INF-g e TNF- $\alpha$, tem sido fortemente associada à imunopatogênese da doença de Crohn. Inclusive, o sucesso da terapia utilizando anticorpos anti-TNF- $\alpha$ reforçam essa hipótese, uma vez que o tratamento com infliximabe, adalimumabe e certolizumabe pegol (conjugado ao polietilenoglicol) tem beneficiado pacientes com doença de Crohn, quando estes estão refratários aos medicamentos convencionais.

Apesar dos avanços obtidos com a terapia anti-TNF- $\alpha$, alguns modelos experimentais têm demonstrado que a produção de TNF- $\alpha$ não se deve exclusivamente à via Th1. Os linfócitos Th17 são estimulados pela IL-23 e, por sua vez, produzem IL-17, IL-6 e TNF- $\alpha$. O envolvimento desse padrão de citocinas na resposta imune da doença de Crohn abre perspectivas para novos alvos terapêuticos importantes.

Curiosamente, em modelos experimentais, a IL-23 demonstrou ser essencial para a inflamação intestinal crônica, por outro lado, a ausência da IL-12 foi irrelevante para o processo inflamatório intestinal. Com isso, é possível questionar qual o real envolvimento da via Th1 na imunopatogênese da doença de Crohn e, ao mesmo tempo, esse fato muda o foco de atenção para a via Th17.

As células Th17 expressam na sua superfície, um complexo de receptores para IL-23, e o receptor de quimiocinas CCR6. A interleucina-23 (formada pelas subunidades p19 e p40), secretada pelas células apresentadoras de antígeno (célula dendrítica), se liga ao complexo de receptores para IL-23 na célula TH17. Essa ligação resulta na ativação da quinase associada a Janus (JAK2) e ativa o fator de transcrição STAT3 (Ativador de transcrição e transdutor de sinal), estimulando a proliferação de células Th17. A célula Th17, ao se ligar à IL-23, produz grandes quantidades de IL-17. Essa citocina, via fator de transcrição NF- $\kappa B$, estimula a produção de citocinas pró-inflamatórias (IL-1 $\beta$, IL-6 e TNF- $\alpha$ ) e o recrutamento de células imunes para o tecido intestinal (Figura 29.3).

Assim o controle da expressão, produção e atividade da via IL-23/Th17 pode representar um caminho para o desenvolvimento de uma nova estratégia terapêutica com maior potencial anti-inflamatório para a doença de Crohn. 


\subsection{6 TRATAMENTO DA DOENÇA DE CROHN}

A terapêutica da doença de Crohn é voltada para a inibição do processo inflamatório exacerbado. Assim, os protocolos recomendados são estabelecidos de acordo com a localização, a gravidade da doença, a resposta à terapia medicamentosa e as possíveis complicações.

A doença ileal ou ileocecal, na forma leve a moderada, pode ser tratada pelo uso de aminossalicilatos por via oral. Os aminossalicilatos disponíveis são a sulfasalazina e a mesalazina. No trato digestivo superior, os aminossalicilatos são pouco absorvidos, permitindo que esses fármacos cheguem de forma inalterada à porção terminal do intestino e ao colón. Nesta região do TGI, a sulfasalazina sofre a ação de azoredutases bacterianas, liberando então o ácido 5-aminossalicílico para agir nos tecidos. A sulfasalazina é o fármaco de escolha para a forma colônica da doença. Diferente da sulfasalazina, a mesalazina é formada apenas pelo ácido 5 -aminossalić́lico, logo não possui os efeitos adversos associados à sulfa, sendo indicada aos pacientes intolerantes à sulfasalazina.

Para pacientes que não toleram aminossalicilatos, pode ser indicado o uso dos antibióticos metronidazol e ciprofloxacina para o tratamento de agudizações leves a moderadas, e também no tratamento de fístulas. Para os pacientes que responderam ao tratamento inicial, a manutenção pode ser realizada com mesalazina, ou budesonide, ou com ausência de terapia em pacientes com remissão clínica no tratamento inicial.

Para pacientes não responsivos à terapêutica inicial, o tratamento pode ser realizado mediante a utilização de corticoides, como a prednisona ou alternativamente a budesonida, ambos administrados pela via oral, podendo ainda ser associados a antibióticos (se houver infecção). Durante a remissão clínica, a manutenção do tratamento desses pacientes deve ser realizada como já descrito acima.

Nos quadros graves da doença de Crohn, as opções de tratamento incluem o uso de imunossupressores, como a azatioprina, 6-mercaptopurina, metotrexato, e ainda terapia biológica. Os pacientes que apresentam dor abdominal intensa, acompanhada de suspeita de obstrução intestinal ou de desnutrição evidente devem ser internados e receber corticoterapia intravenosa, e em casos mais graves, pode ser realizada a ressecção cirúrgica dos segmentos afetados. Após a estabilização do quadro, os pacientes devem ser tratados com prednisona via oral sendo que ao longo do tratamento as doses devem ser gradativamente reduzidas.

A terapia biológica pode ser à base do anticorpo monoclonal quimérico com atividade anti-fator de necrose tumoral (anti-TNF- $\alpha$ ) infliximabe, sendo indicada para a indução e manutenção da remissão em pacientes com doença de Crohn moderada ou grave, não responsivos ao tratamento convencional. Contudo, em um 
estudo com 40 pacientes refratários ao infliximabe, dez apresentaram efeitos indesejáveis, sendo seis considerados graves. Portanto, a reaplicação do infliximabe nesses pacientes deve ser cautelosa. É importante salientar a preocupação resultante de relatos de casos esporádicos, sobre a possibilidade do infliximabe reativar casos de tuberculose. Dessa forma, os pacientes com doença de Crohn devem realizar um método de diagnóstico para tuberculose (reação de Mantoux), e serem submetidos à profilaxia para a tuberculose antes do tratamento com o infliximabe.

Outros fármacos imunossupressores que podem ser utilizados em casos selecionados no tratamento da forma grave da doença de Crohn são a ciclosporina e a talidomida. A ciclosporina possui a capacidade de inibir a produção de várias citocinas (IL-2, IL-3, IL-4, TNF- $\alpha$ e IFN-g), interferindo no processo inflamatório. Já a talidomida também é capaz de aumentar a degradação do RNA mensageiro do TNF- $\alpha$ e inibir a ação da IL-12 e IL-18, reduzindo o processo inflamatório. Além disso, em pacientes refratários ao infliximabe, a talidomida mostrou-se eficaz, reforçando a ideia de que o seu mecanismo de ação não se restringe à inibição do TNF- $\alpha$. Contudo, devido ao forte efeito teratogênico da talidomida, este fármaco tem sido pouco utilizado.

Quando o tratamento médico falha, o tratamento cirúrgico é indicado para mais de $70 \%$ dos pacientes com a doença de Crohn. Nos casos avançados da doença, onde há complicações como estenose, abcessos e fístulas, o tratamento cirúrgico é o mais indicado. Após o procedimento cirúrgico, a remissão da doença deve ser mantida através da utilização de sulfasalazina para o paciente com a manifestação íleo-cólica da doença, a mesalazina é indicada para pacientes com doença localizada ao jejuno e íleo, e, alternativamente, os pacientes podem ser tratados com metronidazol ou azatioprina.

A doença de Crohn hoje é sem cura; contudo, os avanços na descrição dos mediadores inflamatórios envolvidos na patogênese da doença vêm possibilitando a descoberta de outros alvos terapêuticos.

\subsubsection{COLITE ULCERATIVA}

A colite ulcerativa é uma doença crônica caracterizada pela recorrente inflamação da camada mucosa do cólon. A doença pode ser classificada de acordo com a sua localização no cólon, podendo ser denominada de proctite, quando a doença é limitada ao reto, proctossigmoidite, quando afeta até a porção média do sigmóide, colite esquerda, quando envolve o cólon descendente até o reto, e pancolite, quando há o envolvimento de porções proximais à flexura esplênica.

A colite ulcerativa é uma doença recorrente e as recidivas geralmente ocorrem na mesma região do cólon onde houve as lesões anteriores. Embora muitos 
pacientes permaneçam em remissão por longos períodos, a probabilidade de ausência de recidiva por dois anos é de apenas $20 \%$. A sintomatologia da colite ulcerativa consiste em diarreia com ou sem sangramento retal, e dor abdominal frequente. Além disso, a fisiopatologia dessa doença, assim como na doença de Crohn, envolve um conjunto heterogêneo de fatores ambientais e genéticos associados à resposta imune desequilibrada.

A doença de Crohn e a colite ulcerativa são doenças intestinais inflamatórias, contudo é possível identificar diferenças que auxiliam no seu diagnóstico diferencial. A colite ulcerativa manifesta-se exclusivamente no cólon, enquanto que a doença de Crohn pode atingir, além do cólon, as demais regiões do TGI. Na colite ulcerativa são observadas lesões apenas na camada mais superficial do cólon, enquanto que na doença de Crohn toda a parede pode ser atingida. Além disso, a distribuição das lesões na doença de Crohn apresenta áreas de mucosa saudável chamadas de "áreas poupadas”, entremeadas às áreas doentes, enquanto que na Colite Ulcerativa as lesões são difusas e contínuas (sem áreas poupadas) e podem atingir toda a extensão do intestino grosso. Sendo assim, o conjunto dessas diferenças deve ser considerado para o correto diagnóstico.

\subsubsection{EPIDEMIOLOGIA DA COLITE ULCERATIVA}

A colite ulcerativa, assim como a doença de Crohn, é uma doença da sociedade moderna e sua frequência tem aumentado em países desenvolvidos desde meados do século XX (DANESE; FIOCCHI, 2011). A colite ulcerativa pode inicialmente manifestar-se em qualquer idade independente do sexo; contudo, aproximadamente $20 \%$ dos pacientes com colite ulcerativa apresentam os sinais clínicos da doença antes dos 20 anos de idade (HIGUCHI, BOUSVAROS, 2013), com um segundo pico de incidência em idosos com idade variando de 50 a 70 anos.

$\mathrm{Na}$ América Latina, assim como na Ásia, a prevalência da doença é considerada baixa quando comparada com países como os EUA, Reino Unido e Austrália; entretanto, na cidade de São Paulo estima-se a ocorrência de 22,6 casos da doença a cada 100 mil habitantes. Esse fato denota a relevância da colite ulcerativa e a necessidade de mais estudos que demonstrem o real impacto da doença no Brasil (VICTORIA, et al., 2009).

\subsubsection{ASPECTOS CLÍNICOS DA COLITE ULCERATIVA}

A colite ulcerativa geralmente manifesta-se gradualmente. No início da doença, espera-se que o paciente sinta cólicas na região inferior do abdômen acompanhadas por urgência de evacuar, puxo e tenesmo. As primeiras evacuações po- 
dem ser normais quanto à forma e a consistência, porém pode ser constatada a presença de sangue e muco nas fezes. As evacuações subsequentes passam a ser diarreicas e aos poucos o volume das fezes pode diminuir ou ser ausente, ou ainda o paciente pode eliminar apenas muco e sangue.

A sintomatologia da colite ulcerativa pode apresentar particularidades de acordo com a localização da lesão. Quando a doença acomete o reto e o cólon sigmóide, as fezes podem ser normais ou ressecadas e duras. Se a afecção se estender ao restante do intestino grosso, as fezes tornam-se mais líquidas e os pacientes podem ter entre 10 a 20 evacuações por dia seguidas por cólicas intensas e espasmos retais, acompanhados da urgência em defecar.

Complicações sistêmicas em pacientes com colite ulcerativa também são comuns. A doença pode ser acompanhada por artrites, colangite esclerosante primária, espodilite anquilosante, sacroileítes, uveítes e lesões cutâneas como eritema e piodermite gangrenosa e, em crianças, é comum o retardo no crescimento e desenvolvimento.

Para o diagnóstico da colite ulcerativa, é necessário considerar a avaliação da história clínica, exame das fezes, exame radiológico, endoscópico e achados histopatológicos. A história clínica desses pacientes cursa com manifestações e remissões súbitas da doença. Ao exame físico, os pacientes geralmente apresentam pouca alteração e o estado geral pode ser bom ou razoável. Contudo, na forma mais grave da doença a palpação abdominal pode acusar aumento da sensibilidade e dor, principalmente nos quadrantes esquerdos do abdômen. Entre os exames complementares, o exame radiológico contrastado pode oferecer a visualização de todo o cólon, onde é possível identificar perda de elasticidade da víscera e a formação de úlceras finas ou profundas (BERNSTEIN, 2013).

Como a doença pode manifestar-se em áreas do intestino grosso, a retossigmoidoscopia flexível auxilia a definir as porções acometidas. Com isso, a colonoscopia não é normalmente necessária na fase aguda e deve ser evitada, pois pode desencadear um quadro de megacólon tóxico. A análise histopatológica geralmente apresenta as mesmas alterações independentemente da área acometida, onde podem ser visualizados abcessos nas criptas que ajudam a caracterizar a atividade da doença, podendo ser visualizado rompimento de cripta com infiltrado neutrofílico na lâmina própria e, dependendo da fase de evolução e gravidade da doença, o infiltrado pode ser marcado ainda pela infiltração de linfócitos e plasmócitos reforçando a importância do processo inflamatório na patogênese da doença.

Assim como a doença de Crohn, a colite ulcerativa pode ser classificada de acordo com a gravidade da doença, as agudizações são classificadas em três categorias: leve - até três evacuações por dia, com ou sem sangue, sem comprometimento sistêmico; moderada - mais de quatro evacuações por dia com mínimo 
comprometimento sistêmico; e grave - mais de 6 evacuações por dia com sangue e com comprometimentos sistêmicos como febre, taquicardia, anemia (MINISTÉRIO DA SAÚDE, 2002).

\subsubsection{PATOGENIA DA COLITE ULCERATIVA}

A resposta inflamatória exacerbada parece ser o real responsável pela manifestação da colite ulcerativa. O gatilho que inicia todos os eventos patológicos inflamatórios e determina a intensidade dos sintomas, porém está diretamente relacionado a componentes ambientais e genéticos. No contexto da doença, a resposta imune inata e adaptativa parece ser a chave para o maior entendimento da etiologia da doença e para a descoberta de outros alvos terapêuticos.

\subsubsection{RESPOSTA IMUNE INATA NA COLITE ULCERATIVA}

Uma das hipóteses da imunopatologia envolvida na colite ulcerativa refere-se ao defeito na imunidade inata mediada por polimorfismos genéticos nos receptores Toll-like (TLR). A participação dos TLRs na apresentação de antígenos pelos colonócitos é alterada devido à expressão aumentada de TLR2 e TLR4 nessas células.

Sob essas condições, a ativação dos TLRs desencadeia uma cascata de eventos inflamatórios descompensados que resulta na ativação de células dendríticas residentes na mucosa que, após ativadas, estimulam linfócitos da via Th2 a produzir auto-anticorpos como o pANCA (Anticorpo Anticitoplasma Perinuclear Citoplasmático) que reconhecem antígenos nucleares e podem desencadear respostas autoimunes contra as células epiteliais do cólon, e contra as células da pele, olhos, articulações e do epitélio biliar, justificando as manifestações extra-intestinais.

Considerando que a resposta imune na colite ulcerativa pode estar associada a mecanismos alternativos, voltou-se a atenção para as células Natural Killer (NK). As células NK presentes no cólon produzem grandes quantidades de IL-13 e contribuem para a fisiopatologia da doença mediando a citotoxicidade, apoptose e disfunção da barreira epitelial. Este mecanismo envolve glicolípidos oriundos das células epiteliais ou das bactérias, que induzem o aumento da expressão do receptor $\alpha 2$ para IL-13 (IL-13/ $\alpha 2$ ) nas células NK. A ação autócrina da IL-13 ativa as células $\mathrm{NK}$, que se expandem criando um ciclo de retroalimentação positiva que amplifica os efeitos citotóxicos da IL-13 sobre os colonócitos (Figura 29.4).

A resposta autoimune e a ação das células NK contra os colonócitos rompe a barreira epitelial permitindo o contato direto dos micro-organismos com a camada mucosa do colón. Neste ambiente, o elevado número de micro-organismos 
e seus produtos amplifica a resposta imune via receptores TLRs, principalmente o TLR4, aumentando o recrutamento de células efetoras como os neutrófilos, o que pode agravar as lesões e a formação de úlceras no colón, características da doença (Figura 29.4).

O rompimento da barreira epitelial aumenta o contato com os produtos bacterianos. Este contato também pode estimular as células dendríticas e macrófagos, resultando na produção de citocinas pró-inflamatórias (IL-1, IL-6 e TNF- $\alpha$ ) e quimiocinas. As células epiteliais quando ativadas pela IL-1 $\beta$ secretam o Peptídeo Epitelial Ativador de Neutrófilos (ENA-78) e IL-8 (que recrutam neutrófilos), assim como a proteína quimiotática de monócitos (MCP-1), a qual atrai e ativa os macrófagos, que por sua vez, recruta células T efetoras via RANTES. Além disso, Variantes genéticas, redução da expressão do receptor ativado por proliferador de peroxissomo - $\gamma$ (PPAR- $\gamma$ ), anormalidades na produção de muco e na atividade das células Treg também podem contribuir para patogênese de colite ulcerativa (Figura 29.4). 


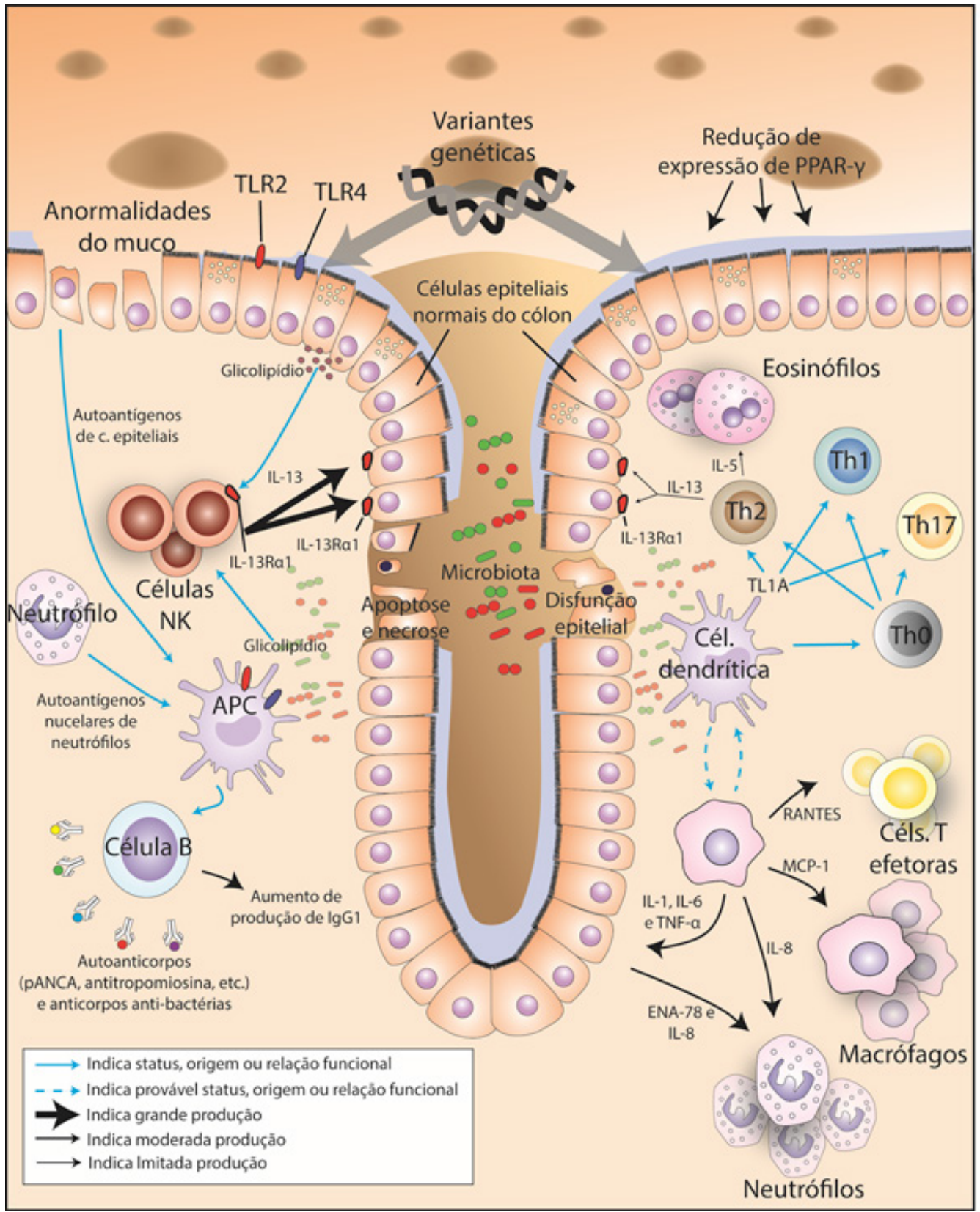

Figura 29.4 - Imunopatologia da colite ulcerativa. 0 defeito na imunidade inata mediada por polimorfismos genéticos nos recep-tores Toll-like (TLR) estão fortemente relacionados à fisiopatologia da colite ulcerativa. A participação dos TLRs na apresentação de antígenos pelos colonócitos é alterada devido à expressão aumentada de TLR2 e TLR4 nessas células. Sob essas condições, a ativação dos TLRs desencadeia uma cascata de eventos inflamatórios descompensados que 
resulta na ativação de células den-dríticas residentes na mucosa, que logo após ativadas, estimulam linfócitos da via Th2 a produzir auto-anticorpos como o pANCA (anticorpo anticitoplasma perinuclear citoplasmático) que reconhecem antígenos nucleares e podem desencadear respostas autoimunes contra as células epiteliais do cólon. As células NK presentes no cólon produzem grandes quantidades de IL-13 e contribuem para a fisiopatologia da doença mediando a citotoxicidade, apoptose e disfunção da barreira epitelial. Este me-canismo envolve glicolípidos oriundos das células epiteliais ou das bactérias, que induzem 0 aumento da expressão do receptor $\alpha 2$ para IL-13 (IL-13/ $\alpha 2$ ) nas células NK. A ação autócrina da IL-13 ativa as células NK, que se expandem criando um ciclo de retroalimentação positiva que amplifica os efeitos citotóxicos da IL-13 sobre os colonócitos. A resposta autoimune e a ação das células NK contra os colonócitos rompe a barreira epitelial permitindo 0 contato direto dos micro-organismos com a camada mucosa do colón. Neste ambiente, o elevado número de micro-organismos e seus produtos amplifica a resposta imune via receptores TLRs, principalmente 0 TLR4, aumentando o recrutamento de células efetoras, como neutrófilos, o que pode agravar as lesões e a formação de úlceras no colón características da doença. Este contato também pode estimular as células dendríticas e macrófagos, resultando na produção de citocinas pró-inflamatórias (IL-1, IL-6 e TNF- $\alpha$ ) e quimiocinas. Neste contexto, as células epiteliais quando ativadas pela IL-1 $\beta$ secretam o Peptídeo Epitelial Ativador de Neutrófilos (ENA-78), IL-8, assim como a proteína quimiotática de monócitos (MCP-1), a qual atrai e ativa os macrófagos que, por sua vez, recruta células T efetoras via RANTES. A imunidade adaptativa na colite ulcerativa é caracterizada por um grande aumento numérico de células Th2 produtoras de IL-5 e IL-13 nos tecidos. A IL-13 produzida pelas células Th2 estimula apoptose dos colonócitos enquanto que a IL-5 é responsável pelo recrutamento de eosinófilos para o local. Além disso, variantes genéticas, redução da expressão do receptor ativado por proliferador de peroxissomo - $\gamma$ (PPAR- $\gamma$ ), anormalidades na produção de muco e na atividade das células Treg também podem contribuir para patogênese de Colite ulcerativa. (Figura adaptada de Danese e Fiocchi,2011).

\subsubsection{RESPOSTA IMUNE ADAPTATIVA NA COLITE ULCERATIVA}

Diferente da doença de Crohn, cujo perfil imunológico da resposta imune é do tipo Th1 e Th17, a resposta imune adaptativa na colite ulcerativa é chamada de "atípica condição Th2". Essa classificação por vários anos foi associada apenas aos baixos níveis de expressão de INF- $\gamma$, a citocina da via Th1. Curiosamente, os níveis de IL-4, principal citocina da via Th2, também não estão aumentados. Em amostras obtidas de pacientes com colite ulcerativa foram identificadas grandes quantidades de IL- 5, e, a partir desse padrão diferenciado de resposta, foi criada a classificação "atípica condição Th2" como o imunofenótipo da colite ulcerativa.

Contudo, recentemente acumulam-se evidências que justificam essa contradição, uma vez que a resposta inflamatória associada à colite ulcerativa também pode ser mediada pela via Th17. Com isso, o perfil da resposta imune Th1/Th17 ou Th2 tem sido utilizado para diferenciar a doença de Crohn da colite ulcerativa.

A tolerância aos antígenos comensais se deve em grande parte a atividade regulatória contínua das células T reguladoras (Treg), as quais são capazes de controlar a resposta imune no intestino através da inibição da proliferação e da atividade de ou- 
tras células T efetoras. Por outro lado, na colite ulcerativa tem sido evidenciado que o número de células Treg está drasticamente diminuído. Esta condição reflete a prevalência da resposta inflamatória exacerbada característica da doença (Figura 29.4).

\subsubsection{TRATAMENTO DA COLITE ULCERATIVA}

O tratamento da colite ulcerativa, assim como o da doença de Crohn, consiste em inibir o processo inflamatório. Nesse sentido, de acordo com a classificação da doença, devem ser utilizados desde anti-inflamatórios de ação local como os aminossalicilatos (sulfassalazina e mesalazina) a fármacos de ação sistêmica como corticóides ou imunossupressores. O tratamento deve ser feito de maneira a tratar a fase aguda e auxiliar na manutenção da remissão, sendo o maior objetivo reduzir a sintomatologia, uma vez que a doença não possui cura.

A manifestação leve a moderada da doença pode ser revertida mediante a utilização de aminossalicilatos como a sulfassalazina ou mesalazina administrados pela via oral ou tópica, por meio de supositório ou enema, dependendo da localização da doença. Em ensaios clínicos, a eficácia da terapia tópica, com supositórios de mesalazina na proctite e enema de mesalazina para a proctossigmoidite, foi superior à ao tratamento pela via oral.

Nos casos em que os pacientes são refratários aos aminossalicilatos ou naqueles onde a forma da doença é classificada como moderada a grave, devem ser tratados com corticoides. A prednisona, por via oral, tem demonstrado bons resultados clínicos, embora existam pacientes que não respondem completamente ao corticoide. Nesses casos é sugerida a utilização de imunossupressores como a azatioprina, 6-mercaptopurina ou terapia anti-TNF.

Pacientes que apresentam a forma grave da doença ou refratários à terapia oral devem ser internados e tratados com corticoide intravenoso. Os não responsivos à terapia intensiva com corticoides devem ser conduzidos à colectomia. Em todos os casos, a remissão da doença deve ser mantida com aminossalicilatos (sulfassalazina ou mesalazina).

Apesar dos avanços no conhecimento da etiologia e dos mediadores da resposta imune envolvidos na patogênese da colite ulcerativa, o tratamento padrão à base de anti-inflamatórios e imunossupressores inibe toda a resposta inflamatória. Essa inespecificidade muitas vezes é responsável por efeitos colaterais e adversos, além de não representar a cura da doença. Assim o entendimento da cadeia de eventos inflamatórios patológicos, inseridos na resposta imune inata e adquirida, possibilitará o reconhecimento de novos alvos terapêuticos capazes de inibir padrões importantes para ciclo de reagudização da doença e assim chegar a um melhor controle da colite ulcerativa e das demais doenças inflamatórias intestinais. 


\section{REFERÊNCIAS BIBLIOGRÁFICAS}

ABBAS, K. B.; LICHTMAN, A. H.; PILLA, S. Imunologia Celular e Molecular. 6 ed. Rio de Janeiro: Elsevier, 2008.

ABRAHAM, C.; CHO, J. H. Inflamatory Bowel Disease. N. Engl. J. Med. 361(21): 2066-2078, 2009.

ABRAHAM, C.; MEDZHITOV, R. Interactions between the host innate immune system and microbes in inflammatory bowel disease. Gastroenterology. 140(6): 1729-1737, 2011.

BERNSTEIN, C. N.; FRIED, M.; KRABSHUIS, J.H. Doença inflamatória intestinal: uma perspectiva global. World Gastroenterology Organisation. Disponível em: <http://www.worldgastroenterology.org>. Acesso em: 22 out. 2013.

CAMPOS, M. J. S.; FERREIRA, A. P.; VITRAL, R. W. The Role of Secretory Immunoglobulin A in the Defense Mechanism of the Oral Mucosa. Pesq. Bras. Odontoped. Clin. Integr. 11(1): 139-143, 2011.

DANESE, S. M. D.; FIOCCHI, C. M. D. Ulcerative Colitis. N. Engl. J. Med. 365(18): 1713-1725, 2011.

DENNING; TIMOTHY, L. D.; WANG, Y.; Patel, S. R. et al. Lamina Propria Macrophages and Dendritic Cells Differentially Induce Regulatory and Interleukin 17-Producing T Cell Responses. Nature Immunology. 8(10): 1086-1094, 2007.

GERSEMANN, M.; WEHKAMP, J.; STANGE, E. F. Innate immune dysfunction in inflammatory bowel disease. Journal of Internal Medicine. 271(5): 421$428,2012$.

HABR-GAMA, A.; CERSKI, C. T. S.; MOREIRA, J. P. T. et al. Diretrizes em Foco, Doença de Crohn intestinal: manejo. Rev. Assoc. Med. Bras. 57(1): 10-13, 2011.

HIGUCHI, L. M.; BOUSVAROS, A. Clinical features and diagnosis of inflammatory bowel disease in children and adolescents. Uptodate. Disponível em: <http:// www.uptodate.com>. Acesso em: 30 ago. 2013. 
JOHNSON, L. R.; GHISHAN, F. K.; KAUNITZ, J. D. et al. Physiology of the Gastrointestinal Tract. 5 ed. Londres: Elsevier, 2012.

KUMAR, V.; ABBAS, A. K.; FAUSTO N.; ASTER, J. C. Robbins \& Cotran Patologia: Bases Patológicas das Doenças. 8 ed. Rio de Janeiro: Elsevier, 2010.

LAMM, M. E. Current concepts in mucosal immunity. IV. How epithelial transport of IgA antibodies relates to host defense. Am. J. Physiol. Gastrointest. Liver Physiol. 274(4): 614-617, 1998.

MALOY, K. J.; KULlBeRG, M. C. IL-23 and Th17 cytokines in intestinal homeostasis. Mucosal. Immunol. 1(5): 339-349, 2008.

MARQUES, R.; BONECA, I. G. Expression and functional importance of innate immune receptors by intestinal epithelial cells. Cell. Mol. Life Sci. 68(22): 3661-3673, 2011.

MESTECKY, J.; LAMM, M. E.; STROBER, W. et al. Mucosal Imunology. 3 ed. Londres: Elsevier, 2005.

MINISTÉRIO DA SAÚDE. Protocolo Clínico e Diretrizes Terapêuticas Doença de Crohn. Portaria SAS/MS n ${ }^{\circ}$ 711, 2010.

MINISTÉRIO DA SAÚDE. Protocolo Clínico e Diretrizes Terapêuticas: Retocolite Ulcerativa. Portaria SAS/MS n $861,2002$.

MÜLLER, A.; OERTLI, M.; ARNOLD, I. C. H. Pylori exploits and manipulates innate and adaptive immune cell signaling pathways to establish persistent infection. Cell Commun. Signal. 9(1): 2011.

OLSEN, T.; RISMO, R.; CUI, G. ET AL. TH1 and TH17 interactions in untreated inflamed mucosa of inflammatory bowel disease, and their potential to mediate the inflammation. Cytokine. 56(3): 633-640, 2011.

PEPPERCORN, M. A. Definition, epidemiology, and risk factors in inflammatory bowel disease. Uptodate. Disponível em: <http://www.uptodate.com>. Acesso em: 30 jul. 2013. 
RUTELLA, S.; LOCATELLI, F. Intestinal dendritic cells in the pathogenesis of inflammatory bowel disease. World J.Gastroenterol.17(33):3761-3775,2011.

SAGAERT, X.; TOUSSEYN, T.; HERTOGH, G. D. et al. Macrophage-related diseases of the gut: a pathologist's Perspective. Virchows. Arch. 460(6): 555$567,2012$.

TATTOLI, I.; TRAVASSOS, T. H.; CARNEIRO, L. A. et al. The Nodosome: Nod1 and Nod2 control bacterial infections and inflammation. Semin. Immunopathol. 29(3): 289-301, 2007.

VICTORIA, C. R.; SASSAK, L. Y.; NUNES, H. R. Incidence and prevalence rates of inflammatory bowel diseases, in midwestern of Sao Paulo State, Brazil. Arq. Gastroenterol. 46(1): 20-25, 2009. 
